\title{
JUDICIALLY NON-ENFORCIBLE PROVISIONS OF CONSTITUTIONS *
}

\author{
Walter F. Dodd $\dot{\dagger}$
}

In the constitutional law of the United States there is a natural tendency to emphasize the judicial enforcibility of constitutional restrictions upon legislative action. This field of our law tends thus to give primary weight to a technical analysis of judicial decisions, at the expense of a consideration of the wisdom and expediency of legislative and executive action. Moreover, it largely overlooks a relatively large field of constitutional regulation not supplemented by judicial enforcibility. We often compare to our advantage the system of judicially enforcible constitutions with that of many other countries in which written constitutions are not judicially enforcible but depend for their effectiveness upon the political forces operating within or upon the government. ${ }^{1}$ Something of more definite value may perhaps be gained from an examination of the provisions of the federal and state constitutions that are not judicially enforcible under our system of constitutional law. To what extent do such provisions exist, and to what extent do they accomplish their purpose as effectively as judicially enforcible provisions?

In the answer to the first of these questions attention must be given to the judicial determinations as to what constitutional provisions are mandatory and what directory. The term mandatory is used in this article to include only those provisions of a constitution that are enforcible against a department of government by some means outside of the department itself. Directory provisions are those not so enforcible.

The political checks of one department upon another suffice to obtain compliance with some constitutional provisions. If, in addition to this, there is to be a continuous power to prevent violations of the constitution, this power must be vested in one of the permanent departments of govern-

*This article is a revision of a chapter prepared some years ago for inclusion in a proposed volume on Constitutional Construction. In the checking of authorities down to date aid has been received from Mr. Victor E. Ferrall, now a Sterling Fellow in the Yale Law School.

There is no intention to discuss here instances of constitutional provisions capable of judicial enforcement, but frequently violated without contest. With respect to appropriations, discussions of this subject will be found in the following articles: Warren, Massachusetts as a Philanthropic Robber (I898) I2 HARv. L. REv. 3I6; Fleisher, Pennsylvania's Appropriations to Privately-managed Charitable Institutions (I915) 30 PoL. Scr. Q. I5. Many statutes escape judicial contest although violative of constitutional provisions.

t A. B., I898, Florida State College; B.S., I901, John B. Stetson University; Ph. D., rgo5. University of Chicago; Professor of Law, Yale University; member of Chicago, Illinois, and American Bar Associations; author of numerous legal and governmental books, and contributor to many legal periodicals.

${ }^{x}$ For a discussion of this subject, see Dodd, Political Safeguards and Judicial Guaranties (Igr5) I5 CoL. L. Rev. 293. 
ment. The experience of Pennsylvania and Vermont with councils of censors demonstrates the futility of attempting to prevent violations of a written constitution through the election of a body to sit occasionally without power to enforce its recommendations.

If a function is committed exclusively and without external control to one department of government, constitutional provisions regarding that matter are directory to that department. This statement applies to the judicial department no less than to the executive and legislative departments. A constitutional command to the judicial department may be enforcible by the highest state court with respect to the lower courts, but a constitutional command to the highest state court is, of necessity, merely directory. For example, a constitutional requirement that the state supreme court report defects in the constitution and laws to the legislature at regular intervals is mandatory in form but directory in fact, and the courts pay little or no attention to the requirement. ${ }^{2}$

The essential difference in the three departments of government with respect to this matter is that few constitutional commands and restrictions are directed to the courts, and not many more to the executive department. The state constitutions are primarily restrictions, upon the legislative department. The distinction between mandatory and directory provisions is therefore more important as to the legislative and executive departments, for in these departments there is a possibility of enforcement through judicial action, and it is most important with respect to the legislature, because that department has the broadest power of affirmative action in determining governmental policy. The court as a body to enforce constitutional restrictions upon itself would almost certainly be ineffective, but if there is to be a continuous enforcibility of constitutional restrictions upon the legislature and the executive, the court is the logical body to exercise such power, not so much because its function is that of construing the law but because of the fact that if there is to be continuous external control, such control can best be vested in the department whose functions least require such external control. The fact that there are few constitutional restrictions upon judicial power is not due to general satisfaction with the judicial department, but rather to the fact that constitutional restrictions and commands are necessarily directed to the legislature as the department of government having power to determine matters of governmental policy.

Under our system of judicial control, the courts not only determine the constitutional issues that are properly before them, but also determine the extent to which the final decision rests in other departments of government as to issues committed in the first instance to such other departments. A 
study of the judicial non-enforcibility of constitutional provisions thus becomes (as elsewhere in our constitutional law) a study of judicial decisions, though in some cases the constitutional provision commits a function so clearly to another department as to make the judicial result a certain one. Yet all courts do not by any means determine the issues in the same manner, nor does the same court adhere to any well-defined principles.

\section{Functions Committed Exclusively to One Department}

Constitutions in some cases clearly commit a function to the uncontrolled discretion of a single department. ${ }^{3}$ For example, the Constitution of the United States and the state constitutions provide that each house of the legislature shall be the judge of the elections, returns and qualifications of its own members. ${ }^{4}$ The same statement holds true where the constitution commits to the legislature for final determination contests as to the governorship or other offices, ${ }^{5}$ or the issue as to whether a constitutional amendment has been adopted. ${ }^{6}$ The refusal of the court to decide such cases is not based on a view that the questions are of a type improper for judicial consideration, but on the ground that the matters are exclusively committed to another department. Where power is not constitutionally denied to them, courts will exercise jurisdiction in such matters. ${ }^{7}$

When the governor or president is authorized to call extra sessions of the legislative bodies "on extraordinary occasions," discretion is clearly committed to the executive as to what constitutes an extraordinary occasion, although the Kansas court suggests that complete discretion here may not be uncontrolled. ${ }^{s}$ Constitutional provisions authorizing the governor to

"On this matter, see Cooley, Constitutional Limitations (8th ed. I927) IoI-ro3.

- State ex rel. Attorney General v. Tomlinson, $20 \mathrm{Kan} .692$ (1878); Opinion of the Justices, 56 N. H. 570 ( 1875 ) ; Naumann v. Board of City Canvassers, 73 Mich. 252, 4I N. W. 267 (I889) ; People ext rel. Bruce v. Dunne, 258 IIl. 44 r, 456-466, IOT N. E. 560, 566-569 (I913); Opinion of Justices, $7 \mathrm{Me} .483$ (1830); Attorney General ex rel. Beers v. Board of Canvassers, I5.5 Mich. 44, Ir8 N. W. 584 ( 1908 ) ; State ex rel. Boulware v. Porter, 55 Mont. 47I, I78 Pac. 832 (I9I9) ; State ex rel. Alexander v. Pharr, 179 N. C. 699, I03 S. E. 8 (I920) ; State $e x$ rel. Barbes v. Circuit Court, I78 Wis. 468, Igo N. W. 563 (I922); Dingerman v. Board of Canvassers, 198 Mich. I35, I64 N. W. 492 (I9I7) ; Davis v. Wilson et al., $35 \mathrm{~S}$. W. (2d) 1020 (Ark. I93I). Other cases are collected in CoOLEy, op. cit. supra note 3, at 270, n. 3. A similar rule seems properly applicable to members of constitutional conventions, whether the constitution expressly so provides or not. Dod, REvision AND AMENDMEnt of State Constitutions (I9I0) 88, n. 28. Local legislative bodies are frequently given power to pass finally on the election and qualification of their members. Sinclair v. Common Council, I8I Mich. I86, I47 N. W. 942 (I9I4).

"Taylor v. Beckham, 108 Ky. 278,56 S. W. I77 (1900), reviewed in 178 U. S. 548, 20 Sup. Ct. 890 (1900).

Worman v. Hagan, 78 Md. 152, 27 Atl. 616 (1893).

7 For authorities regarding election contests see infra notes I59-166. For cases regarding judicial power with respect to constitutional amendments see infra note I72.

${ }^{3}$ Whiteman v. Railroad Co., 2 Harr. 514, 524 (Del. I839); Opinion, 9 Colo. 642, 21 Pac. 477 (1886) ; Farrelly v. Cole, 60 Kan. $356,374,56$ Pac. 492,498 ( 1899 ). But see State v. Howat, IO7 Kan. 423, 430, I9I Pac. 585, 589 (I920). For general statements regarding the governor's power to call special sessions, see Simpson v. Hill, I28 Okla. 269, 263 Pac. 635 (1927) and Dyer v. Shaw et al., I39 Okla. I65, 28I Pac. 776 (I929). Where the constitution limits the special session to matters specified by the governor, such a limitation is judicially enforcible. 
adjourn the legislature, upon disagreement of the two houses with respect to the time of adjournment, appear to commit to the governor's uncontrolled determination the issue as to whether there is a sufficient disagreement between the two houses, but this is perhaps not quite so clear as in the case of calling extraordinary sessions. ${ }^{9}$

So, also, where a constitution vests in a governor power to remove certain officers for a specified cause, the governor's determination that such cause exists is not subject to judicial inquiry, although the courts disagree as to whether the officer is entitled to notice and hearing. ${ }^{10}$ Where notice and hearing are said to be necessary, the power is regarded as a quasijudicial power vested exclusively in the governor. Similarly the power of impeachment, while judicial in its nature, is vested exclusively in the legislative bodies. ${ }^{11}$ "If a court is required to give an accused person a trial at the first term after indictment, unless good cause be shown for continuance, it is obvious that the question of good cause is one for the court alone to pass upon, and that its judgment when exercised is, and must be from the nature of the case, final." 12

When a constitution provides that laws shall not take effect until a future date unless in case of emergency declared in a certain manner by the legislature, it would appear that the legislature has an uncontrolled discretion to determine whether an emergency exists. ${ }^{13}$ To comply with the constitution there must be a declaration of an emergency, ${ }^{14}$ but under similar constitutional language the courts are in disagreement as to whether the grounds of the emergency must be specified. The Illinois constitution requires that the "emergency shall be expressed in the preamble or body of the act", and the Illinois court requires that the grounds of the emergency be set out, although apparently it will not inquire into the sufficiency of the facts alleged to constitute the emergency. ${ }^{15}$ Under almost identical consti-

${ }^{P}$ People ex rel. Harless v. Hatch, 33 Ill. 9 (1863) ; In re Legislative Adjournment, 18 R. I. 824, 27 Atl. 324 (I894); Report of AttorNey General of IllinoIs (I9I2) 73; Note (I894) 22 L. R. A. 716.

See Coyle v. Smith, 28 Okla. I2I, II3 Pac. $944^{\circ}$ (IgII) for a discussion of the power of the governor to convene the legislature at another place than the seat of government "when in his opinion the public safety or welfare, or the safety or health of the members, require it."

${ }^{10}$ Wilcox v. People, go Ill. 186 (1878) ; People ex rel. Johnson v. Coffey, 237 Mich. 59I, 213 N. W. 460 (I927) ; State ex rel. Ulrick v. Sanchez, 32 N. M. 265, 255 Pac. I077 (I927). Tuttle, Removal of Public Officers From Office for Cause (I905) 3 Micr. L. Rev. 290, 34I. See also Note (I9I2) 39 L. R. A. (N. S.) 788.

"State v. Chambers, 96 Okla. 78, 220 Pac. 890 (1923).

II ConLey, op. cit. supra note 3 , at ro3.

${ }^{13}$ Carpenter v. Montgomery, 7 Blackf. 415 (Ind. I845) ; Note (1920) 7 A. L. R. 519. In Martin v. Hidalgo County, 27 I S. W. 436 (Tex. I925) the Texas Court of Civil Appeals said at 438: "The Constitution permits the Legislature to release counties, cities, or towns from payment of taxes levied for state or county purposes in case of great public calamity, and to the Legislature alone is confided the power of deciding if such public calamity exists."

14 State v. Pacific Express Co., 80 Neb. 823, II5 N. W. 619 (1908).

${ }^{15}$ Graham v. Dye, 308 Ill. 283 , I39 N. E. 390 (I923). See also Biggs v. McBride, I7 Ore. 640,21 Pac. 878 (1889). Under the referendum in Maine the emergency must be ex- 
tutional language the Virginia. court reaches a result directly opposed to that of Illinois. ${ }^{16}$ The Kentucky constitution requires that the reasons for the emergency "be set out at length in the journal of each house", and the Kentucky court will apparently consider the sufficiency of the reasons, ${ }^{17}$ though this runs counter to the general view.

Since the introduction of the referendum in a number of states, emergency declarations have presented a new problem. In these states it is common for constitutions to provide that the referendum shall not apply to laws that are necessary for the immediate preservation of the public peace, health or safety. ${ }^{18}$ The purpose of the referendum is to permit a popular vote upon legislative enactments. An unrestrained declaration of emergencies by the legislature would defeat this purpose. In six sessions of the South Dakota legislature, running from I899 to I909, emergency clauses were inserted into 537 acts of the $125 \mathrm{I}$ that were passed. ${ }^{19}$ The constitution of Maryland postpones the operation of a law "unless it contain a section declaring such law an emergency law", and thus makes it certain that the legislative judgment is final as to the existence of an emergency. ${ }^{20}$ Other constitutions do not determine the issue, and the courts of Washington, ${ }^{21}$ California, ${ }^{22}$ Michigan, ${ }^{23}$ South Dakota, ${ }^{24}$ Arkansas, ${ }^{25}$ Montana ${ }^{26}$ and Missouri ${ }^{27}$ take the view that legislative declarations of emergency are subject to judicial review; the view of the Ohio court upon this matter is uncertain; ${ }^{28}$ the courts of Oregon, ${ }^{29}$ Oklahoma, ${ }^{30}$ Colorado ${ }^{31}$

pressed in the preamble and approved by a two-thirds vote. These requirements are judicially enforcible, though the grounds of emergency appear not to be open to judicial question. Payne v. Graham, II8 Me. 25I, I07 Atl. 709 (IgI9).

${ }^{10}$ City of Roanoke v. Elliott, I23 Va. 393, 96 S. E. 819 (19I8) ; Breckenridge v. County School Board, I46 Va. I, I35 S. E. 693 (I926).

${ }_{17}$ McIntyre v. Commonwealth, $221 \mathrm{Ky} .16,297 \mathrm{~S}$. W. 93 I (I927).

is Dodn, State Government (2d ed. ig28) 535-537.

Io Loweld, Public Opinion ANd PopUlar Government (1921) 175.

${ }^{2}$ Culp v. Commissioners of Chestertown, I54 Md. 620, I4I Atl. 4 IO (1928).

" State v. Meath, 84 Wash. 302, I47 Pac. II (Ig15); State v. Hinkle, I52 Wash. 221, 277 Pac. 837 (I929).

${ }_{22}$ In re McDermott, I80 Cal. 783, I83 Pac. 437 (I919).

${ }^{23}$ Attorney General v. Lindsay, I78 Mich. 524, I45 N. W. 98 (I9I4); Naudzius v. Lahr, 253 Mich. 2I6, 234 N. W. 58 I (193I).

${ }_{24}$ Johnson v. Jones, 48 S. D. 260, 204 N. W. 15 (I925) ; State v. Smith, 49 S. D. I06, 206 N. W. 233 (1925); In re Opinion of Judges, 234 N. W. 67I (S. D. I93I).

Jumper v. McCollum, I79 Ark. 837, I8 S. W. (2d) 359 (1929).

*State v. Stewart, 57 Mont. I44, I87 Pac. 641 (I920).

$\pi$ State v. Sullivan, 283 Mo. 546, 224 S. W. 327 (I920); Hollowell v. Schuyler County, 322 Mo. 1230, 18 S. W. (2d) 498 (1929).

${ }^{2}$ State v. Smith, 102 Ohio St. 59I, I33 N. E. 457 (I92I). But see statement in dissenting opinion in State v. Fremont, II6 Ohio St. 469,479, I57 N. E, 3I8, 320 (I927). The issue also appears to be unsettled in North Dakota. State v. Crawford, $36 \mathrm{~N}$. D. 385,162 N. W. 710 (I9I7).

$\rightarrow$ Kadderly v. Portland, 44 Ore. II8, 74 Pac. 710 (I903); Cameron v. Stevens, I2I Ore. 538,256 Pac. 395 (I927). But the court will inquire into the facts as to a declaration of emergency in an ordinance. Joplin v. Ten Brook, I24 Ore. 36, 263 Pac. 893 (I928).

${ }^{\circ}$ Oklahoma City v. Shields, 22 Okla. 265, 100 Pac. 559 (Ig08).

${ }^{3}$ Van Kleeck v. Ramer, 62 Colo. 4, 156 Pac. Iro8 (1916); Shields v. City of Loveland, 74 Colo. 27, 218 Pac. 913 (1923). 
and Arizona ${ }^{32}$ adhere to the view of uncontrolled legislative discretion. To some extent, this conflict of opinion is based upon differences of constitutional language, but in the main it is a difference of judicial opinion. The Montana court distinguishes its view from that of Oregon on the basis of a difference in constitutional language, but the distinction seems untenable. The Oregon referendum provision was largely copied by Colorado, Missouri and Washington. The Colorado court regards the Oregon decisions as to legislative discretion as controlling; the Missouri and Washington courts reject this view and regard the question of emergency as open to judicial review. The Arkansas court originally held the legislative determination conclusive, but changed its view upon the adoption of a state constitutional amendment in I9I8 specifically requiring a legislative statement of the facts constituting the emergency and a separate vote thereon. In a number of states the courts have thus brought under judicial control a power theretofore regarded as within the unrestricted control of legislative bodies.

In some cases constitutional language is so clear that the courts can give nothing of mandatory force to a provision; of this character is the provision in the constitution of New Jersey that:

"The legislature shall pass general laws providing for the cases enumerated in this paragraph, and for all other cases which, in its judgment, may be provided for by general laws." 33

But where the language is not so clear, one must discover what the court of the particular state says as to the provision involved. The Wisconsin constitution provides that "the legislature shall establish but one system of town and county government, which shall be as nearly uniform as practicable." The degree of practicable uniformity would seem to be committed to the legislature, but the Supreme Court of Wisconsin says this is not so, although it concedes a broad discretion to the legislature. ${ }^{34}$

The constitution of Mississippi says that "every bill introduced in the legislature shall have a title and the title ought to indicate clearly the subjectmatter or matters of the proposed legislation"; the Mississippi court holds, with much show of reason, that "ought" in this connection made the provision as to nature of title directory, although the requirement of title is mandatory. ${ }^{35}$ Somewhat similar was the Missouri constitutional provision

${ }_{22}$ Orme v. Salt River Valley Water Users' Ass'n, 25 Ariz. 324, 217 Pac. 935 (I923).

${ }^{83}$ N. J. Const. of 1844 , art. $4, \$ 7$, cl. II. The Mississippi constitution is even more explicit in this matter, Miss. Const. of 1890 , art. $4, \S 90$.

" State ex rel. Peck v. Riordan, 24 Wis. 484 (1869) ; State ex rel. Scanlan v. Archibold, 146 Wis. 363, I3I N. W. 895 (IgII).

* Mayor v. State, I02 Miss. 663. 59 So. 873 (I9r2) ; Lang v. Board of Supervisors, II4 Miss. 34I, 75 So. 126 (I917). 
declaring that "all property subject to taxation ought to be taxed in proportion to its value"; the provision here was held to forbid taxation in any other manner than in proportion to value, the court taking occasion to say that the word ought as used in a number of constitutional provisions was clearly mandatory. ${ }^{36}$

A number of state constitutions, after enumerating subjects in detail in which local or special legislation is forbidden, declare that: "In all other cases where a general law can be made applicable, no special law shall be enacted." The language of this provision is more mandatory than that of the Wisconsin clause referred to above, but the view of state courts in general is that the provision has no judicial enforcibility against the legislature, ${ }^{37}$ and this view is justified by the fact that the constitutional language specifically enumerates the things expressly forbidden and implies that the legislature is to determine "where a general law can be made applicable" in other cases. Yet the courts of California, Oklahoma and Montana have taken the view that no legislative discretion exists to pass a special law in a case where, in the judicial opinion, a general law has already been made applicable. $^{38}$ This makes the clause accomplish the same purpose as the more specific one in Georgia and Maryland that no special law shall be enacted "in any case for which provision has been made by an existing general law." The latter type of provision appears clearly subject to judicial enforcement. ${ }^{39}$

In addition there seems now a tendency toward the view that the question as to "where a general law can be made applicable" is fully open to judicial inquiry. The Indiana court for a while took this position. ${ }^{40}$ The South Carolina Supreme Court, after much vacillation, appears to have decided that it is for the court to determine in last resort whether a general law could have been made applicable, ${ }^{41}$ and a similar point of view has

${ }^{30}$ Life Association of America v. Board of Assessors, 49 Mo. 512 (I872).

${ }^{3}$ Merrills, Some Aspects of Judicial Control over Special and Local Legislation (I913) 47 AM. L. Rev. 35I. People v. Borgeson, 335 Ill. 136, I46, I66 N. E. 45 I, 455 (I929).

${ }^{39}$ Ventura County Harbor Dist. v. Board of Supervisors, 295 Pac. 6 (Cal. I930); White v. Infield, I22 Okla. 4, 250 Pac. 81 (Ig26) ; State v. Meyers, 65 Mont. 124, 210 Pac. I064 (I922).

${ }^{33}$ State v. Baltimore \& O. R. R. Co., II3 Md. 179, 77 Atl. 433 (Igro); O'Dowd's Sons v. City of Augusta, I4I Ga. 748,82 S. E. I48 (1914).

Section 105 of the Alabama constitution forbids a special, private or local law "in any case which is provided for by a general law, or when the relief sought can be given by any court of this state; and the courts, and not the legislature, shall judge as to whether the matter of said law is provided for by a general law, and as to whether the relief sought can be given by any court".

th Thomas v. Board of Commissioners, 5 Ind. 4 (1854); Board of Commissioners v. Fetter, I93 Ind. 288, 296, I39 N. E. 45I, 454 (I923).

41 Barfield v. Stevens Mercantile Co., 85 S. C. I86, 67 S. E. 158 (1909). Later South Carnlina cases attribute great weight to the legislative determination, and appear to seek an "equal protection of the laws" basis for their decision. Thomas v. Spartanburg Ry. Gas \& Electric Co., I00 S. C. 478,85 S. E. 50 (1914) ; City of Columbia v. Smith, 105 S. C. 348,89 S. E. 1028 (1916) ; Sirrine v. State, 132 S. C. 241 , I28 S. E. I72 (1925). 
recently been expressed by the courts of Montana, Nebraska, New Mexico, North Dakota, Oklahoma and Wyoming. ${ }^{42}$ The Missouri constitution of I875 expressly provided that whether a general law could have been made applicable shall be a judicial question, and several states have followed Missouri's example; ${ }^{43}$ but it is obvious that the courts can accomplish the same result without change in the constitutional text. The judicial decisions as to declarations of emergency and as to special legislation make it sufficiently clear that constitutional texts alone cannot be relied upon to determine what matters are committed exclusively to legislative and executive determination.

\section{Mandatory and Directory Provisions}

American courts have, however, differed most as to the mandatory or directory character of certain constitutional limitations within the field of legislative procedure. Constitutional limitations within this field fall into two classes :

(I) Provisions whose observance or violation must be discovered by evidence external to the enactment of the legislature itself; $e . g$., requirements as to three readings of the measure in each house, as to recording of ayes and nays upon the passage, as to the requisite majority of members for passage, as to printing of bills before final passage, as to committee reports required in the consideration of bills, and public notice required by some constitutions of application for local and special legislation.

(2) Those the observance or violation of which may be discovered by examining the text of the statute enacted by the legislature; $e . g$., requirements as to titles of bills, amendment by reference, form of enacting clause, separation of appropriations from substantive legislation. Provisions of this character, when couched in obligatory language, are in most cases held to be mandatory and judicially enforcible; although to this statement at least one exception must be made, for in Ohio a constitutional provision that "no bill shall contain more than one subject, which shall be clearly expressed in its title", is held to be merely of a directory character. ${ }^{44}$

These two classes of limitations are found in close relation to each other in constitutional texts, particularly with reference to the enactment

2 State v. Schofield, 53 Mont. 502, I65 Pac. 594 (I9I7) ; Cunningham v. Douglas County, I04 Neb. 405, 177 N. W. 742 (1920); Scarbrough v. Wooten, 23 N. M. 616, 170 Pac. 743 (I9I8) ; Baird v. Rask, 234 N. W. 65I (N. D. I93I) ; School District No. 85 v. School District No. 7I, I35 Okla. 270, 276 Pac. I86 (I928); State v. Snyder, 30 Wyo. 287, 219 Pac. 735 (1923). See also Stratman v. Commonwealth, I37 Ky. 500, I25 S. W. I094 (I9I0).

${ }^{4}$ Minnesota (1892), Kansas (1906), Michigan (1908). For a similar provision in Alabama, see supra note 39 . See Merrills, op. cit. supra note 37.

" Oshe v. State, 37 Ohio St. 494 (1882), and cases there cited. A similar statutory provision with respect to ordinances is held to be mandatory. Hefner v. City, 75 Ohio St. 413, 80 N. E. 8 (1907). 
of legislation and the proposal of constitutional amendments. For example, the constitution of Maine provides that in case of declarations of emergency to withdraw an act from the referendum, legislative action shall be by a two-thirds vote of all the members, "with the facts constituting the emergency . . . expressed in the preamble of the act". Formal compliance with the one requirement can be discovered from the face of the act; with respect to the other, resort must be had to the legislative journals. In at least one case a constitution makes it clear that the two types of provisions are judicially enforcible. The Alabama constitution requires that certain things be done in the enactment of local and special legislation and that journal entry be made thereof, and then adds:

"The courts shall pronounce void every special, private or local law which the journals do not affirmatively show was passed in accordance with the provisions of this section." 45

But there are few provisions of this character.

If the enactment of a measure by the legislature is itself regarded as conclusive that all steps in its passage have been properly taken, clearly the provisions in the first class just referred to are directory, for nothing upon the face of the measure indicates compliance or non-compliance with them. The question becomes therefore one of proof. If the enrolled bill (i.e., the enactment as it comes from the legislature) is conclusive, these provisions rest for their enforcement upon the legislative bodies alone. If proof may be sought for in the records of legislative proceedings, the court may then enforce legislative compliance with the requirements, or at least, enforce the entry of a record upon legislative journals that such compliance has been had. In some cases it would be substantially impossible to enforce compliance even to the extent of requiring a journal entry. Where a constitution requires that a bill be distinctly read, no journal entry of the legislative body could indicate the distinctness of the reading, and no court would seek to inquire into the compliance with such a requirement; it would be regarded as within the judgment of the legislative body.

All of the state constitutions either directly or indirectly require the legislative bodies to keep journals. As to use of these journals to test compliance with constitutional forms, two situations present themselves: (I) The constitution requires certain procedural steps but does not expressly require journal entry to the effect that these steps were taken; (2) The constitution requires certain steps and also expressly requires journal entry to the effect that the steps have been taken. Although a more clearly mandatory character would appear to attach to provisions reinforced by

t5 Alabama constitution of I90I, art. 4, § I06. 
an express requirement of journal entry, the courts have not always distinguished between the two types of provisions just referred to.

The tendency of the courts has been to regard the enrolled bill as conclusive when the constitution itself requires no record of compliance with prescribed forms of legislative procedure; this accords with the presumption that in absence of proof to the contrary public officers have done their duty. Absence of record should raise no presumption of non-compliance. ${ }^{46}$ The most important recent exception to the statement just made is the Illinois case of Neiberger $v$. McCullough. ${ }^{47}$ The Illinois constitution of 1870 requires that a "bill and all amendments thereto shall be printed before the vote is taken on its final passage". The constitution does not expressly require that a journal entry indicate that such printing actually took place, though journal entries are expressly required with respect to some of the other constitutionally prescribed steps in legislative procedure. The Supreme Court of Illinois held that a law would be unconstitutional unless it appeared from the journals that printing was had in compliance with constitutional requirements, but later decisions have substantially abandoned this position. ${ }^{48}$

Where the journals themselves affirmatively show non-compliance (although required to show nothing) a presumption that there has been compliance would naturally be weakened. Some constitutions require public notice, in the locality affected, of intention to apply for the passage of a local or special law, but do not require a record of such notice in the journals; under such provisions the practice of courts in general is to assume that the passage of a local or special law carries with it conclusive proof that notice was given in the manner required; the Pennsylvania court, however, held that a local act was unconstitutional where it was clear that no notice had been given. ${ }^{49}$ And the courts of Arkansas and Florida have taken the view that they would not conclusively presume the notice to have been given when the period required for such notice was longer than the interval intervening between the calling of a special session and the enact-

'Upon this whole matter, see Sutherland, Statutory Construction (Lewis' ed. I904) $\$ \S 32-59$; and an excellent note, (IgII) $40 \mathrm{~L}$. R. A. (N. S.) I. A note of earlier cases will be found in (1894) $23 \mathrm{~L}$. R. A. 340. With respect to absence of journal entries when none are constitutionally required, see State v. Joseph, I39 La. 734, 72 So. I88 (1916); State v. City of Palmetto, 99 Fla. 40I, 406, I26 So. 781, 783 (I930); Ex parte Seward, 299 Mo. 385, $397-8,253$ S. W. 356,358 (I923).

${ }^{47} 253$ Ill. 3I2, 97 N. E. 660 (I9I2).

ss See Dragovich v. Iroquois Iron Co., 269 Ill. 478, 109 N. E. 999 (I9I5) ; People ex rel. Zeno v. State Board of Dental Examiners, 278 I1l. I44, I15 N. E. 852 (I9I7). The Illinois court sought ingeniously in several cases to prevent contest of earlier and well-established laws on the ground asserted in the Neiberger case. Greenberg et al. v. City of Chicago et al., 256 IIl. 213,99 N. E. I039 (I9I2) ; Richter v. Burdock, 257 Ill. 4 IO, I00 N. E. I063 (I9I3).

${ }^{20}$ Chalfant v. Edwards, I73 Pa. 246, 33 Atl. 1048 (I896) ; see also Brodnax v. Groom, 64 N. C. 244 (1870). 
ment of the law. ${ }^{50}$ In New Jersey the courts decline to follow the rule of presuming notice to have been given, becaurse of the enactment of the special law, but the New Jersey constitutional provision requiring such notice is aided by a requirement that the legislature "shall prescribe the time and mode of giving such notice, the evidence thereof and how such evidence shall be preserved." The legislature had prescribed the manner of giving notice and preserving evidence thereof. The requirement with respect to preservation of notice was treated as equivalent to a requirement of record of such notice, to which the courts might resort to impeach the enactment. ${ }^{51}$ The New Jersey cases are based, therefore, primarily upon the ground that there is a constitutional requirement, supported by necessity of record as to compliance therewith.

Where it is permitted, local and special legislation is peculiarly subject to abuse, and a requirement of notice before introducing such legislation is of no value if the passage of the measure raises a conclusive presumption that notice was given. For this reason the Missouri constitution requires that "the notice shall be recited in the act". The court can thus determine from the face of the act, without examining the journals, that the legislature declares notice to have been given. The constitution of Florida was amended in 1928 to require that "affidavit constituting proof of publication be attached to the bill when introduced and be entered in full upon the journals". This creates a mandatory duty, for the Florida courts examine the legislative journals, where the constitution requires journal entry. ${ }^{52}$

Where a constitution requires a certain procedure (as that the vote shall be by ayes and nays on the final passage of all bills), and also expressly requires journal entry of compliance with such requirement, the view naturally suggests itself that the added requirement of journal entry directs the court to the journal as the standard by which to test compliance with the requirement. This view would appear to be the more natural one. The South Carolina court has stated that it is within the power of the court "to inquire into those prerequisites fixed by the constitution, and of which prerequisites the journals of the two houses are required to furnish evidence"; and the courts of North Carolina and Montana feel that they are required

${ }^{50}$ Booe v. Road Improvement District, I4I Ark. I40, I5I, 216 S. W. 500, 504 (I9I9); Ark-Ash Lumber Co. v. Pride \& Fairley, I62 Ark. 235, 258 S. W. 335 (I924); Horton v. Kyle, 8I Fla. 274, 88 So. 757 (192I). But the insufficiency of time was required to be shown to a certainty. Conlee v. Miller, I44 Ark. 56, 221 S. W. 465 (1920); State e.r. rel. Buford v. Fearnside, 87 Fla. 349, 360, I00 So. 256, 259 (I924).

${ }^{51}$ Freeholders of Passaic County v. Stevenson, 46 N. J. L. 173 (1884) ; Township of Ewing v. City of Trenton, 57 N. J. L. 318, 31 Atl. 223 (I894); Attorney General v. Borough of Tuckerton, 67 N. J. L. I20, 50 At1. 602 (I90I).

\& Whitney v. Hillsborough County, 99 Fla. 628, I27 So. 486 (I930) ; Douglas v. Webber, $99 \mathrm{Fla} .755$, I28 So. 613 (I930). 
by the constitution to examine the legislative journals under certain conditions. ${ }^{.33}$

In Missouri requirements of certain action and of journal entry thereof are supplemented by a provision that:

"No bill shall become a law until the same shall have been signed by the presiding officer of each of the two houses in open session; and before such officer shall affix his signature to any bill, he shall suspend all other business, declare that such bill now be read, and that, if no objections be made, he will sign the same to the end that it may become a law. The bill shall then be read at length, and if no objection be made he shall, in the presence of the house, in open session, and before any other business is entertained, affix his signature, which fact shall be noted on the journal. . . . If in either house any member shall object that any substitution, omission or insertion has occurred, so that the bill proposed to be signed is not the same in substance and form as when considered and passed by the house, or that any particular clause of this article of the constitution has been violated in its passage, such objection shall be passed upon by the house, and if sustained, the presiding officer shall withhold his signature; but if such objection shall not be sustained, then any five members may embody the same, over their signatures, in a written protest, under oath, against the signing of the bill. Said protest, when offered in the house, shall be noted upon the journal, and the original shall be annexed to the bill to be considered by the governor in connection therewith."

It was urged with some plausibility that this provision committed to the legislative bodies finally the determination as to procedural requisites of legislation, but a majority of the Missouri court took the view that the enacted measure might be impeached by an examination of the legislative journals, ${ }^{54}$ and a statute was held invalid because the journals showed passage by less than the requisite constitutional majority.

Unaided by such a provision as that in Missouri ${ }^{55}$ the courts of some states have, however, taken the view that legislative journals may not be examined to impeach an enrolled bill, even when a constitution expressly requires compliance with a procedural form to be noted on the journals.

${ }^{2}$ State ex rel. Hoover v. Town Council of Chester, 39 S. C. 307,317, I7 S. E. 752, 755 (I893); Carr v. Coke, II6 N. C. 223, 22 S. E. I6 (I895) ; State ex rel. Woodward v. Moulton et al., 57 Mont. 4I4, 426, I89 Pac. 59, 64 (1920). But the courts of Montana and North Carolina base their decisions on obligatory language in the constitutions, which they regard as torcing them to examine the journals in a single instance only.

a State ex rel. Schmoll v. Drabelle et al., 26I Mo. 515, I70 S. W. 465 (IgI4). See the interesting dissent by Judge Graves. It may be that the judges are influenced by their knowledge that the bills are not read at length, and that the Missouri provision (constitution of 1875, art. 4, § 37) and a similar one in New Mexico (constitution of 1912, art. 4, §20) are in certain respects complied with only to the extent of proper journal entries.

$\omega$ But a member of states require signature by presiding officers, either in the presence of the house or otherwise, and this is given weight in the decisions holding that the bill so signed may not be impeached by the examination of journals. 
The courts of California, ${ }^{56}$ Georgia, ${ }^{57}$ Kentucky,58 Nevada ${ }^{59}$ and New Mexico ${ }^{60}$ have taken this view in cases necessarily involving the decision of the issue; but the Kentucky court now recognizes at least one exception to this rule. The courts of Indiana, ${ }^{61}$ Iowa, ${ }^{62}$ Mississippi, ${ }^{63}$ Pennsylvania, ${ }^{64}$ South Dakota ${ }^{65}$ and Washington ${ }^{66}$ have made positive statements in support of the conclusiveness of the enrolled bill, but the cases in which these statements were made do not appear necessarily to have involved journal entries expressly required by the constitutions of those states. Montana and North Carolina ${ }^{67}$ adopt the same view, with a single exception in each state. The South Carolina court makes broad statements to the same effect, but apparently does not intend to foreclose its power to examine journal entries required by the constitution. ${ }^{68}$ The New Jersey case of State $v$. Young, ${ }^{69}$ is frequently quoted in support of the finality of the enrolled bill, and this view has the support of later New Jersey cases; ${ }^{70}$ but since 1873 the statutes have authorized a proceeding, to be brought within one year, to determine whether a statute has been duly passed or duly approved "as required by the constitution", and in this type of proceeding the courts will

${ }^{\circ}$ County of Yolo v. Colgan, I32 Cal. 265, 64 Pac. 403 (Igor). In California the doctrine of finality is carried a step farther. The California constitution provides that after a municipal charter amendment has been ratified by a vote of the people the legislature may approve or reject it as a whole. The court held that this provision clearly placed the duty upon the legislature to see trat the proceedings by which the charter amendments were proposed to the people were regular in all respects; and that since the amendment in question had been approved by the legislature and duly enrolled and filed as a law its validity (as to the manner of its proposal to the people) could not be questioned. Taylor v. Cole, 20I Cal. 327, 257 Pac. $40(1927)$.

${ }^{57}$ DeLoach v. Newton, I34 Ga. 739, 68 S. E. 708 (1910) ; Atlantic Coast Line R. R. Co. v. The State, I35 Ga. 545, 69 S. E. 725 (1910); Dorsey v. Wright, 150 Ga. 32I, I03 S. E. 59 I (I920).

${ }_{63}$ Lafferty v. Huffman, 99 Ky. 80, 35 S. W. I23 (I896) ; Duncan v. Combs, I3I Ky. 330 , II5 S. W. 222 (I909). But the Kentucky court goes back of the enrolled bill with respect to declarations of emergency, the constitution requiring the reasons to be set out in the journals. See supra note 17 .

${ }^{59}$ State ex rel. Osburn v. Beck, 25 Nev. 68, 56 Pac. 1008 (1899).

${ }^{\infty}$ Kelley v. Marron, 21 N. M. 239, I53 Pac. 262 (I9I5); Smith v. Lucero, 23 N. M. 41 , I68 Pac. 709 (Igr8).

Evans v. Browne, 30 Ind. 514 (1869).

State ex rel. Hammond v. Lynch, I6g Iowa I48, I5I N. W. 8I (I9I5); Davidson Building Co. v. Muiock, 235 N. W. 45 (Iowa I93I).

${ }^{\omega}$ Ex parte Wren, 63 Miss. 512 (1886) ; State ex rel. Collins v. Jackson, II9 Miss. 727, 8r So. I (Igrg).

Kilgore v. Magee, $85 \mathrm{~Pa}$. $40 \mathrm{r}$ (1877).

"Narregong v. Brown County, 14 S. D. 357,85 N. W. 602 (Igor) ; Kiakowski v. Wasker, 33 S. D. 33.5, 145 N. W. 566 (I9I4).

cs State v. Jones, 6 Wash. 452, 34 Pac. 20I (1893) ; State v. State Board, I40 Wash. 433, 249 Pac. 996 (r926). There is a strong dictum to the same effect in Arizona. See Allen v. State, 14 Ariz. 458, I30 Pac. III4 (I9I3). See also cases cited in King v. Terrall, 218 S. W. 42 (Tex. Civ. App. 1920).

7 See supra note 53 .

\& Wingfield v. South Carolina Tax Commission, I47 S. C. II6, I28, I44 S. E. 846,850 (1928); Williamson v. Richards, 158 S. C. 534, I55 S. E. 890 (1930).

${ }^{\infty} 32$ N. J. L. 29 (I866).

${ }^{70}$ Passaic v. Stevenson, 46 N. J. L. I73 (I884) ; Bloomfield v. Freeholders of Middlesex, 74 N. J. L. 26I, 65 Atl. 890 (Ig07). But see In re Hague, 104 N. J. Eq. 3I, 5I, I45 Atl. 618 ( I929). 
admit evidence as to the legislative proceedings. ${ }^{71}$ Moreover, New Jersey makes an exception with respect to notice of local and special legislation. ${ }^{72}$ Field $v$. Clark ${ }^{73}$ appears to commit the United States Supreme Court squarely to the doctrine of the finality of the enrolled bill, and has the support of recent approval in Leser $v$. Garnett; ${ }^{74}$ but Mr. Justice Harlan's language in Field $v$. Clark and Harwood $v$. Wentworth ${ }^{\mathrm{T}}$ implies an exception of expressly required journal entries, and there is some doubt as to what the court may decide should the journals not show "the names of the persons voting for and against the bill", as required by Article I, Section 7, of the Constitution, when bills are passed over the president's veto.

The Georgia court has well expressed the rule as to the finality of the enrolled bill :

"When an enrolled act is signed by the presiding officers of both houses, approved by the governor, and deposited in the office of the secretary of state, it will be conclusively presumed that the measure was properly put to a vote in both houses, and that it received a constitutional majority; and the court will not upset the act because the journals of the houses happened to show that it did not receive a majority of the votes of either or both branches of the legislature." 76

This view was somewhat more broadly expressed by the Supreme Court of Washington:

"Finding an enrolled bill in the office of the secretary of state, unless that bill carries its death warrant in its hand, the courts will make no investigation of the antecedent history connected with its passage, except as such an investigation may be necessary in case of ambiguity in the bill for the purpose of determining the legislative intent." $7 \tau$

There is much basis in fact for the view that as to procedural matters an enrolled bill may not be impeached by reference to legislative journals, even though journal entries as to such procedural steps are expressly required by the constitutional text. The refusal to go to the journals results, of course, in making these provisions directory-commits the observance of such requirements to uncontrolled legislative discretion. Several reasons unite to cause courts to reach this result:

( $\tau$ ) The court can inquire only as to whether there is journal entry of compliance with constitutional forms, not whether there is actual com-

${ }^{71}$ In re Petition of Attorney General, 98 N. J. L. 586, 12I Atl. 736 (1923).

72 Passaic v. Stevenson, 46 N. J. L. I73 (I884).

73 I43 U. S. 649, I2 Sup. Ct. 495 (I892).

74258 U. S. 130, 42 Sup. Ct. 217 (I922).

т I62 U. S. 547, 562, I6 Sup. Ct. 890, 894 (1895).

7 Atlantic Coast Line v. State, I35 Ga. 545, 55I, 69 S. E. 725, 728 (Igro).

7 State v. State Board, 140 Wash. 433, 443, 249 Pac. 996, 1000 (1926). 
pliance. Some constitutions require that bills be read three times at length in each house; this requirement is one which, if complied with, cumbers legislative procedure, without being of any real value; if the constitution requires journal entry of three readings in full, such journal entry may be had but it does not indicate that there were in fact three readings. Requirements as to entry of ayes and nays on final passage of each bill are often met also by proper journal entries, not by real compliance. Such provisions are often mandatory, therefore, only to the extent to which they make necessary formal journal entries of things not in fact done.

(2) Legislative journals are often kept carelessly, and constitute in many cases the poorest sort of evidence. A statute attacked on the basis of imperfect journal entries may therefore be held unconstitutional upon such a basis, not so much because of defect in legislative procedure as because of error or intentional omission by clerical officers. ${ }^{\text {is }}$ If courts go back of the journals to receive proof as to accuracy of journal entries they have an interminable task, and they must almost of necessity decline to do this. ${ }^{79}$

(3) In view of the difficulties as to character of evidence which the journals afford and of the small value of that exidence in establishing actual compliance with procedural forms, courts may well decline so unprofitable and ineffective a task as the examination of legislative journals. A definite and more easily applicable rule is established if the enrolled bill be treated as conclusive. A frequently presented additional reason for this view is well stated in an opinion of the Towa court:

"Indeed, to preserve the harmony of our form of government, these mandatory provisions must be considered as addressed to the department which is called upon to perform them and neither of the other departments will be permitted in any manner to coerce that department into obedience thereto. Those courts which uphold the inquiry as to whether the legislature has observed the mandatory provisions of the constitution necessarily assume that it were safer to entrust the enforcement of these to the judicial department than the legislature, and that the judicial department is the only one in which sufficient integrity exists to insure observance of the provisions of the constitution. Such an attitude seems intolerable." so

${ }^{7}$ Cases are full of comments upon the untrustworthy character of legislative journals. See State $c x r c l$. Hammond v. Lynch, I69 Iowa I48, I5I N. W. 8I (IgI5); Kelley v. Marron, 2 I N. M. 239, I53 Pac. 262 (I9I5).

70 Taylor v. Beckham, I08 K $2-8,56$ S. W. 177 (I900) ; Capito v. Topping, 65 W. Va. 587. 64 S. E. 845 ( 1909 ); SutherLAND, op. cit. supra note 46, at \$\$ 45-48; but see Jackson Lumber Co. v. Walton County, 95 Fla. 632,659 , I16 So. $771,78 \mathrm{I}$ (1928); Hull v. City of Humboldt, 107 Neb. 326, 186 N. W. 78 (I92I); In re Petition of Attorney General, supra note $7 \mathrm{I}$.

${ }^{80}$ State ex rel. Hammond v. Lynch, I69 Iowa I48, 156, I5I N. W. 8I, 84 (19I5). The court uses the word "mandatory" in a sense different from that employed in this paper. 
The rule of finality of the enrolled bill is subject to severe test when there is an allegation and offer to prove that the enrolled bill signed by the presiding officers of the two houses is not the measure actually adopted by the two houses. A variance of the enrolled bill from the measure actually adopted is normally not shown by any journal entries that are expressly required by the constitution. The supreme courts of the United States and of Mississippi and North Carolina met the issue by declining to examine the journals, ${ }^{81}$ although in the North Carolina case the journals pretty clearly showed that the purported act had not been introduced in one house and had been tabled in the other. An opposite view was taken in the states of Florida, North Dakota and Illinois, which have not adopted the rule of finality of the enrolled bill. In North Dakota a bill passed by the house and amended in the senate was reported back to the house in a form different from that in which it left the senate, the senate thereupon passing and entering upon its journals a resolution denouncing the action that had been taken. Passage of the incorrect bill and its enrollment were successfully challenged by resort to the journal. ${ }^{82}$ In Florida an act was held bad because containing thirty-three sections which the journals showed to have been stricken from the bill; ${ }^{83}$ and a similar fate befell an Illinois law in which the bill submitted to the governor omitted fourteen amendments adopted by the two houses. ${ }^{84}$

Where the violation of a constitutional provision may be determined from the text of the enactment itself, a simpler problem is presented to the court. If such a constitutional provision has been violated, the "bill carries its death warrant in its hand". The distinction between such provisions and those requiring resort to the journals has been generally recognized. But the Ohio court draws a different line of distinction. It holds provisions relating only to the mode of legislation to be directory, as for example, that requiring the purpose to be clearly stated in the title; violation can here of course be discovered by examination of the enactment. It holds provisions to be mandatory which affect power or authority to enact a law, as for example, that requiring a concurrence of a majority of all members elected to each house for the passage of a statute; violation here can, of course, be discovered only by an examination of the journals. ${ }^{85}$

With respect to provisions requiring that a bill after passage be signed by the presiding officer of each house, compliance may be determined by

st Field v. Clark, I43 U. S. 649, I2 Sup. Ct. 495 (1892); Ex parte Wren, 63 Miss. 5 I2 (I8S6); Carr v. Coke, II6 N. C. 223, 22 S. E. 16 (1895).

$\approx$ State v. Schultz, 44 N. D. 269, I74 N. W. 8r (I9I9).

${ }^{\circledR}$ State v. Deal, 24 Fla. 293,4 So. 899 (I888). The court discusses other cases of a similar character.

Bs People v. Leuders, 283 Ill. 287, II9 N. E. 339 (I9I8).

\& Miller v. State, 3 Ohio St. 475 (1854) ; State v. Kiesewetter, 45 Ohio St. 254, 257, I2 N. E. 807,808 (1887). 
examining the bill as passed; though the requirement that there be journal entry of signature in the presence of the house becomes directory in states that regard the enrolled bill as final. ${ }^{86}$ Some difference of judicial opinion exists as to whether such provisions should be regarded as mandatory, but apparently most of the courts passing upon the question have held that such signatures must be had. ${ }^{87}$ In several cases the courts say that the enrolled bill is properly conclusive against attack through an examination of legislative journals, in large part because the constitution requires final authentication to be given to it by the presiding officers. Such authentication is in these cases regarded as more controlling than the journals. The time of signature is ordinarily endorsed on the bill, and compliance or non-compliance with constitutional requirements as to such time may be discovered by examining the enrolled act. The Kansas constitution requires that bills passed by the two houses shall "within two days thereafter be signed by the presiding officers and presented to the governor". By some judicial legerdemain this is construed to be directory as to time of signature by presiding officers and mandatory as to time of presentation to the governor. ${ }^{88} \mathrm{~A}$ requirement that no bill be presented to the governor within two days before adjournment would apparently compel resort to the journals if the governor approved the bill or allowed it to become law without his signature, and would under such conditions be unenforcible in states declining to go back of the enrolled bill. ${ }^{89}$

The form of the enacting clause can always be determined by examining the enrolled bill, and almost all of the state constitutions prescribe the form of enacting clause, ${ }^{90}$ although in Oklahoma the prescribed form is held to apply only to bills enacted under the initiative and referendum clause of the constitution. ${ }^{91}$ There is authority for the view that the provision for

${ }^{30}$ State v. Bacon, 14 S. D. 394, 85 N. W. 605 (I90I) ; State v. Moulton, 57 Mont. 414, I89 Pac. 59 (1920) ; State v. Long, 21 Mont. 26, 52 Pac. 645 (1898).

st Lynch v. Hutchinson, 219 III. I93, 76 N. E. 370 (I906); State ex rel. Hammond v. Lynch, 169 Iowa 148, 15I N. W. 8I (I9I5); State ex rel. Attorney General v. Mead, 7I Mo. 266 (1879); State ex rel. Cardwell v. Glenn, 18 Nev. 34, I Pac. I86 (I883) ; State v. Kiesewetter, supra note 85 ; State ex rel. McClay v. Mickey, 73 Neb. 281,102 N. W. 679 (I905). But see Commissioners of Leavenworth Co. v. Higginbotham, I7 Kan. 62 ( 1876 ), and State v. Missouri Pacific Ry. Co., I00 Neb. 700, 704, I6I N. W. 270, 271 (1916). Scarborough v. Robinson, 8I N. C. 4Io (I879) says that signatures of presiding officers are necessary, but this is doubted in Wrought Iron Range Co. v. Carver, II8 N. C. 328, 24 S. E. 352 (I896).

${ }_{s s}$ Aiken v. Edwards, 55 Kan. 75I, 42 Pac. 366 (I895); State v. Ryan, I23 Kan. 767, 256 Pac. 8I I (1927). In Florida signature by presiding officers is construed to require signature during the legislative session. Amos v. Gunn, 84 Fla. 285, 94 So. 6I5 (I922). See also State v. Ryan, supra, and State ex rel. McClay v. Mickey, supra note 87. With respect to possible necessity for second authentication on passage over governor's veto, see State v. State Board, I40 Wash. 433, 249 Pac. 996 (I926) ; City of Evansville v. State, r I8 Ind. 426, 21 N. E. 267 (1888), and State v. Howell, 26 Nev. 93, 64 Pac. 466 (Igor).

${ }^{\infty}$ Bender v. State, 53 Ind. 254 (1876); State ex rel. Owen v. Fortieth Judicial Circuit et al. 174 N. E. 423 (Ind. I93I).

${ }^{\infty}$ SUTHERLAND, op. cit. supra note 46 , at $\$ \S 69-72$. For enacting clause requirements see Index Digest of State Constitutions (I915) 832 .

ox Ex parte Hudson, 3 Okla. Cr. 393, 106 Pac. 540 (I9ro) ; Turner v. McCain, 26 Okla. 132, Iog Pac. 821 (1910). 
an enacting clause is purely directory and that a statute entirely without one is valid, ${ }^{02}$ but in other cases statutes have been held invalid where there was no such clause. ${ }^{9 s}$ An enacting clause is seldom completely absent, and the more important question is that as to the effect of an enacting clause varying from that prescribed. The Maryland court has said that the requirement is directory, but in the cases in which this statement was made the variation from the constitutionally required clause was not material ${ }^{94}$ In a case in which the legislature used the word "resolved" instead of "be it enacted", the Mississippi court said :

"There are no exclusive words in the constitution negativing the use of any other language, and we think the intention will be best effectuated by holding the clause to be directory only." 95

In a case almost parallel with that of Mississippi, the South Carolina court held the enacting clause mandatory but took the view that the requirement had been substantially complied with. A variation justified in Mississippi on the ground that the provision was directory, was held proper in South Carolina as substantial compliance with a mandatory requirement. ${ }^{96}$ Under similar conditions the Kansas court was of the opinion that there had been sufficient compliance. ${ }^{97}$ In an Illinois case involving much the same facts as those in Mississippi, South Carolina and Kansas, the enacting clause was held improper. ${ }^{98}$ The Nevada court in 1875 expressed the view that enacting clause requirements were mandatory and that nothing but the "very words" of the constitutional clause would suffice, but such a broad statement was not required, for the enacting clause before the court appeared not to meet even in a substantial manner the constitutional requirement. ${ }^{99}$ In the Tennessee case of State ex rel. Gouge $v$. Barrow ${ }^{100}$ the words "the state of" were omitted from the constitutionally prescribed enacting clause, so that the clause read, "Be it enacted by the general assembly of Tennessee." The court took the view that the enacting clause requirement was clearly mandatory, but upheld the statute, saying:

City of Cape Girardeau v. Riley, 52 Mo. 424 (1873). See also City of St. Louis v. Foster, 52 Mo. 513 (1873), and Creason v. Yardley, 272 Mo. 279, I98 S. W. 830 (1917).

${ }^{\curvearrowleft}$ People v. Dettenthaler, 118 Mich. 595, 77 N. W. 450 ( 1898 ) ; Sjoberg v. Security Savings and Loan Association, 73 Minn. 203, 75 N. W. III6 (I898); State v. Patterson, 98 N. C. 660,4 S. E. 350 ( 1887 ) ; Commonwealth v. Illinois Central Railroad Co., I60 Ky. 745, I70 S. W. 17I (1914); Vinsant v. Knox, 27 Ark. 266, 284-286 (187r).

"McPherson v. Leonard, 29 Md. 377 (1868) ; Postal Telegraph Cable Co. v. State, Iro Md. 608, 73 Atl. 679 (1909). But see Prince George's County v.'Baltimore \& O. Ry. Co., II3 Md. 179, 77 Atl. 433 (I9I0).

${ }^{\infty}$ Swann v. Buck, 40 Miss. 268, 293 (1866).

${ }^{\infty}$ Smith v. Jennings, 67 S. C. 324, 330-332, 45 S. E. 821, 823-824 (1903).

"State v. Knapp, I02 Kan. 7or, I7I Pac. 639 (I9I8).

${ }^{\infty}$ Burritt v. Commissioners, I20 Ill. 322, II N. E. I80 (I887).

${ }^{2}$ State ex rel. Chase v. Rogers, Io Nev. 250 (1875).

${ }^{100}$ II9 Tenn. 376, 391, I04 S. W, 526, 530 (190\%) 
"While some courts of last resort have held, as we do, that the constitutional provision here invoked is mandatory, yet no case has been called to our attention where a statute has been held void for a failure to comply with that provision, when the enacting clause used necessarily and conclusively expressed the same meaning and had the same effect, although not literally in the form used."

Perhaps the conclusion may be drawn from the cases on this subject that the weight of authority gives mandatory effect to constitutional provisions requiring enacting clauses; but that what is mandatory is a substantial, not a complete and literal, compliance. ${ }^{101}$ The use of the precise language is not mandatory, but the courts must determine in each case what is substantial compliance. An enacting clause was recently held sufficient which used the words "be it enacted, etc.," instead of "be it enacted by the general assembly of the State of Louisiana." 102 Constitutional requirements with respect to the concluding words of an indictment present a similar problem. ${ }^{103}$

${ }_{101}$ Louisville Trust Co. v. Morgan, I8o Ky. 609, 203 S. W. 555 (I9I8) ; State v. Harries, 47 La. Ann. 386, I7 So. I29 (I895); Fowler v. Stone, I49 Ga. 125, 99 S. E. 291 (I9I9); Kefauver v. Sparling, 154 Tenn. 6I3, 290 S. W. I4 (I926).

${ }_{102}$ City of Shreveport v. Dale, I49 La. 439,89 So. 408 (192r).

100 The general view appears to be that provisions prescribing the words with which an indictment shall conclude are mandatory and an indictment may be bad if it omits the phrase and contains no equivalent declaration. Revill v. State, 87 Tex. Cr. I, 218 S. W. 1044 (I920). Some courts have said that a literal compliance is necessary to a valid indictment. Lemons v. State, 4 W. Va. 755 (1870); Williams v. State, 27 Wis. 402 (187I); Clingan v. State, 135 Miss. 62I, I00 So. I85 (I924). The weight of authority is, however, that the provision although mandatory requires only a substantial and not a literal compliance, and immaterial variations have been permitted. State v. Kean, ro N. H. 347 (1839); Smith v. Jennings, 67 S. C. $324,332,45$ S. E. 821, 824 (1903); Kirkham v. People, I7o Ill. 9, 48 N. E. 465 (1897); People v. Larsen, 265 Ill. 406, 106 N. E. 947 (rgr4); Webb v. Commonwealth, I22 Va. 899, 94 S. E. 773 (I9I8). But what constitutes a material compliance? The Missouri constitution requires that an indictment conclude, "against the peace and dignity of the state". An indictment for rape in the case of State v. Campbell, 210 Mo. 202, 223, 227, 109 S. W. 706, 7II, 7I2-7I3 (I907) omitted the second "the". The court said: "As heretofore pointed out, the authorities are all in harmony that the conclusion to the indictment must substantially conform to the requirements of the constitution, and in all cases where this proposition has been in judgment before the appellate courts, where the language used was not identical with the terms prescribed by the constitution, it is significant that the courts have uniformly pointed out that the terms used were equivalent and in effect and substance embraced the conclusion required by the constitution. - . This being true, it is plainly manifest that, the definite article 'the' which should immediately precede the word 'state' being omitted, the conclusion to the indictment in the case at bar falls far short of indicating the power or authority against which the facts charged in the body of the indictment constitute an offense. authority against which the facts conclusion prescribed by the constitution of this state is not only one of form, but as well one of substance: 'substance because the constitution requires it'; and, as was said by Mr. Bishop in the announcement of the rule, "whatever alters the substance, even in what seems unimportant, will render it void." A case identical in conclusion with State v. Campbell is Smith v. State, I39 Ala. I15, 36 So. 727 (I903). The Missouri court adhered to the Campbell case for some years (Stone v. Warner, 220 Mo. 23, II9 S. W. 399 (Ig09)), a court of appeal saying in a dictum that the Campbell case would require it to hold an information bad if a word in the constitutional formula were misspelled. State v. Calvin, r6o Mo. App. 723,142 S. W. 470 (I9I2). But in State v. Adkins, 284 Mo. 680, 225 S. W. 981 (I920) the Supreme Court of Missouri expressly overruled the Campbell case, saying that the omission of "the" was not a fatal defect. The Missouri court said in 1917 that the requirement that process run in the name of the "State of Missouri" is directory (Creason v. Yardley, 272 Mo. 279, I98 S. W. 830 (1917)), and recently took the view that the conclusion to an indict- 
The processes involved in the amendment of state constitutions through legislative proposal raise issues very similar to those regarding the processes of legislation. Requirements with respect to constitutional amendments may be grouped into three classes: (I) those compliance or non-compliance with which may be determined from the face of the proposed amendment, as, for example, the requirement that the proposal shall relate only to one subject or to but one article of the constitution; (2) those compliance or non-compliance with which may be determined from an examination of legislative journals, as, for example, the provision regarding the legislative vote necessary to propose, and the requirement that a proposed amendment be "entered" or "enfered in full" on the legislative journals; (3) those compliance or non-compliance with which can be determined in neither of these ways, but must be discovered by examining other evidence, as, for example, the requirement that a proposed amendment be published in each county of a state for three months before the election at which it is to be submitted.

In view of the judicial attitude in many states with respect to processes of legislation, it would be natural to expect courts to hold some of the provisions as to the amending process to be directory. But aside from two or three possible exceptions, this seems not to be the case as to any one of the three classes of provisions referred to in the preceding paragraph. It has been suggested that the courts sometimes treat immaterial requirements as if they were directory, ${ }^{104}$ but even the most liberal cases have hardly gone as far as this, although there is a dictum to this effect in the Pennsylvania case of Commonwealth $v$. Griest: ${ }^{105}$

"We think that the provision as to publication three months before the next general election, as prescribed in the first clause of article I8, should be regarded as merely a directory provision, where strict compliance with a time limit is not essential."

The Idaho court once intimated in a dictum, subsequently questioned, that though two-thirds of the members of each house did not vote for a pro-

ment is a mere matter of form, the omission of which may be cured by amendment after trial has begun. State v. Riddle, 324 Mo. 96,23 S. W. (2d) I79 (1929).

The doctrine of substantial compliance may apparently affect a mathematical standard set up by the constitution. The New York constitution contains the requirement that variations in assembly districts should not exceed the population of a town or block adjoining such district, but the court said that a trivial and technical difference would be overlooked. Matter of Dowling, 2Ig N. Y. 44, II3 N. E. 545 (I9I6). And where a constitution required districts to be formed of contiguous territory, the court said that one county was exempt from the requirement because of its population and geographical location. Matter of Sherrill v. O'Brien, I88 N. Y. I85, 8I N. E. I24 (I907).

${ }^{104}$ See collection of cases in Note (I907) Io L. R. A. (N. S.) I49. In statutes, time of action is often treated as directory, but time of submission of constitutional amendment has been held mandatory in Alabama and Kansas. Johnson v. Craft, 205 Ala. 386, 87 So. 375 (I92I); Hooper v. Fox, 206 Ala. 37I, 89 So. 593 (I92I); State v. Sessions, 87 Kan. 497, I24 Pac. 403 (I9I2).

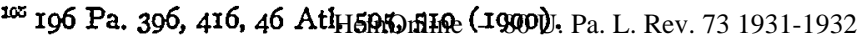


posed amendment, if the measure had been put on the ticket without objection and approved by the people, an estoppel would operate to prevent a contest of its validity after popular approval, although objections might have been made at an earlier stage of the proceedings. ${ }^{106}$ Recent decisions of the Pennsylvania Supreme Court go farther than the Idaho dictum and hold that "the approval by the people gives unattackable validity . . . to constitutional amendments submitted to them"; ${ }^{107}$ and the California court has recently made a somewhat similar statement. ${ }^{108}$

Although there is a respectable body of decision and of dictum to the effect that enrolled bills may not be impeached by journal entries, courts appear in substantially all cases to have examined journals in order to determine whether proposed constitutional amendments have been entered upon legislative journals as required by provisions for amending constitutions. The Supreme Court of Iowa has indulged in vigorous statements in favor of the conclusiveness of enrolled bills, but has in the past been especially strict in resorting to journals to test validity of proposed constitutional amendments. ${ }^{109}$ It is difficult to determine whether this difference of attitude on the part of the Iowa court represents a change of view, or a position that the court should be stricter with respect to constitutional amendments; or a view that journal entries while untrustworthy to test legislative enactments, are trustworthy to test steps in the proposal of constitutional change. The South Carolina court, which professes to give finality to enrolled bills, will examine the journals for the aye and nay vote on proposed constitutional amendments. ${ }^{110}$ The Montana court has explicitly stated that the rule as to the finality of enrolled bills does not apply to proposed constitutional amendments. ${ }^{111} \mathrm{~A}$ contrary view has been expressed in South Dakota, but does not seem necessary to the decision of the case. ${ }^{112}$ Only in New Mexico is it clearly decided that journal entries will not be permitted to impeach a proposed constitutional amendment. In Smith $v$. Lucero ${ }^{113}$ the journal of the state senate showed less than a constitutional majority voting for the proposal of an amendment, but the New Mexico court said:

${ }^{200}$ Holmberg v. Jones, 7 Idaho 752, 758-759, 65 Pac. 563, 564 (IgoI) ; McBee v. Brady, I5 Idaho 76I, I00 Pac. 97 (I909). See ivifra notes I79-I8I for cases in which courts decline to question important constitutional changes that have once become effective.

${ }^{207}$ Armstrong v. King, 28I Pa. 207, I26 Atl. 263 (1924); Taylor v. King, $284 \mathrm{~Pa}$ 235, I30 Atl. 407 (1925).

${ }^{1003}$ Wright v. Jordon, I92 Cal. 704, 221 Pac. 9r5 (r923).

${ }^{103}$ Koehler and Lange v. Hill, 60 Iowa 543, I4 N. W. 738 (1883) ; State ex rel. Bailey v. Brookhart, II3 Iowa 250, 84 N. W. 1064 (IgOI).

${ }^{120}$ Lucas v. Barringer, I20 S. C. 68, II2 S. E. 746 (I922) ; Stevenson v. Carrison, I22 S. C. 212, II5 S. E. 25 I (1922).

211 Martien v. Porter, 68 Mont. 450, 465, 219 Pac. 8I7, 819 (I923).

${ }^{112}$ State v. Schmidt, 42 S. D. 267 , I73 N. W. 838 (I9I9).

${ }^{113} 23$ N. M. 4II, 4I9, I68 Pac. 709, 7I2 (1918). 
"We are aware that in California, Iowa, Nevada, Missouri and Montana a different conclusion is reached. In those states and others, it is held that the journal is the source of evidence as to what was done in the proposal of constitutional amendments, and that the ordinary rule that resort cannot be had to the journal to impeach the enrolled and authenticated act of the Legislature has no application. In those states, however, they have no such provision as we have in regard to the enrolling and engrossing of all bills and resolutions and have therefore no such declared policy as to the evidence of legislative action: Cases from those states are collected in the note to Palatine Insurance Co. v. Northern Pac. Ry. Co., 34 Mont. 268, 85 Pac. I032; 9 Ann. Cas. 579, 587."

Except as to journal entries in New Mexico and possibly South Dakota, and attacks after popular approval in Pennsylvania and possibly California, little or no difficulty presents itself to the courts as to proof of non-compliance with constitutional requirements in the proposal and adoption of constitutional amendments. The requirements are judicially enforcible. The real issue that presents itself here is, assuming these provisions to be mandatory, does a substantial compliance suffice? Where a proposed amendment is required to be published for three months before an election and is actually published for only two weeks, clearly there is not a substantial compliance. ${ }^{114}$ But a more doubtful case presents itself when an amendment is not published until sixty days before election when the constitution requires ninety days. ${ }^{115}$ Where a proposed amendment is required to be published once each week in at least one newspaper in each county where a newspaper is published, for three months (or for twelve weeks) before an election, it is clear that there was substantial compliance even though publication in one county was for one week less than the time specified. ${ }^{116}$ The weight of judicial view is that substantial compliance suffices, although of course there may be difference of view as to what compliance is substantial.

It may be argued that a constitutional provision is not completely mandatory unless literal compliance with its terms is judicially enforced, and this is true. In the cases here discussed the word mandatory has either one of two meanings: it is employed sometimes in the stricter sense of re-

214 State v. Tooker, I5 Mont. 8, 37 Pac. 840 (1894); State v. Cline, II8 Neb. 150, 224 N. W. 6 (I929).

${ }^{110}$ McCreery v. Speer, I56 Ky. 783, I62 S. W. 99 (I9I4).

${ }^{\text {us }}$ State ex rel. Thompson v. Winnett, 78 Neb. 379, IIO N. W. III3 (Ig07); Russell v. Croy, I64 Mo. 69, 93, 95, 63 S. W. 849, 85I, 852 (I90I); Fahey v. Hackmann, 29I Ma 35I, 370-376, 237 S. W. 752, 757-760 (I922); Sandell v. City of Omaha, II5 Neb. 86I, 215 N. W. I35 (I927); Manos v. State, 98 Tex. Cr. 87, 263 S. W. 310 (I924); State v. Alderson, 49 Mont. 387, I42 Pac. 210 (Igr4). Prohibitory Amendment cases, $24 \mathrm{Kan}$. 700, 710 (I88I). See also State v. Grey, 2I Nev. 378, 32 Pac. I90 (1893), and Commonwealth v. Griest, I96 Pa. 396, 46 Atl. 505 (I900). 
quiring literal compliance; and at others is used to denote a compliance not necessarily literal, but at least substantial. Statements in the cases frequently go farther than is necessary to dispose of the issue involved. With respect to mandatory and directory provisions (whether in the legislative and amending processes or elsewhere), judicial statements which approach the character of dicta may be grouped into three classes: (I) Cases in which there has been a substantial compliance with constitutional forms, but in which the court said that such forms were directory. The same result would have been reached had the court said that the form was mandatory, but with substantial compliance sufficing. (2) Cases in which it is assumed that a requirement is mandatory and the question is one as to whether it shail be liberally or strictly construed. Shall a requirement of "entry" of a proposed constitutional amendment be construed to require "full entry"? The arguments for a liberal interpretation in favor of the legislature in such a case are much the same as those supporting a view that formal provisions are directory, but statements sometimes found in such cases that such provisions are directory are unnecessary to the decision of the issue before the court. The issue is that as to the construction of a mandatory requirement, although as to journal entry it is sometimes bound up with the question whether (assuming a certain construction of a mandatory requirement) substantial or literal compliance with that requirement is necessary. ${ }^{117}$ (3) Cases in which there was no substantial compliance with constitutional provisions, but in which the court says that a literal compliance is necessary. The result in such cases may equally well be based upon the argument that the constitutional provisions involved are mandatory to the extent of requiring substantial compliance, but that substantial compliance was not had. ${ }^{118}$

Judge Cooley's language ${ }^{119}$ upon directory and mandatory provisions has often been quoted:

u" Some constitutions require "full" entry-others require entry. Montana requires that proposed amendments agreed to by the two houses "be entered in full on their respective journals". Full entry on the house journals alone was held substantial compliance. Martien v. Porter, 68 Mont. 450, 219 Pac. 8I7 (I923). Iowa requires entry only, and full entry on the journals of the two houses with a slight and immaterial variation between the two was held fatal. See supra note rog. The Wisconsin court at first held entry to mean entry in full, but on rehearing, held an identifying entry sufficient. State v. Marcus, I60 Wis. 354, I52 N. W. 419 (1915) (three judges dissenting). For earlier cases, see DoDd, op. cit. sitpra note 4, at I44-I48. Later cases in New York, Wisconsin, North Dakota, Utah, Nevada, Oregon and Washington hold entry to require only an identifying reference. Browne v. City of New York, 241 N. Y. 96, I49 N. E. 2 II (1925); State v. Hall, 44 N. D. 459, 17I N. W. 213 (I9I8) ; Lee v. Price, 54 Utah 474, I8I Pac. 948 (I919); Ex parte Ming, 42 Nev. 472 , I8r Pac. 3I9 (I9I9) ; Boyd v. Olcott, I02 Ore. 327, 202 Pac. 431 (192I); Gottstein v. Lister, 88 Wash. 462, 467, 153 Pac. 595,597 (1915). A contrary view was taken in McAdams v. Henley, 169 Ark. 97, 273 S. W. 355 (I925) which gives a good brief review of the cases.

${ }^{113}$ State ex rel. Chase v. Rogers, Io Nev. 250 (1875). See also State v. Tooker, 15 Mont. 8, 37 Pac. 840 (1894); and Varney v. Justice, 86 Ky. 596, 6 S. W. 457 (I888).

${ }^{11} O p$. cit. sitpra note 3 , at I59-160. See pages 154-I64 for Cooley's full discussion of this subject. 
"But the courts tread upon very dangerous ground when they venture to apply the rules which distinguish directory and mandatory statutes to the provisions of a constitution. Constitutions do not usually undertake to prescribe mere rules of proceeding, except when such rules are looked upon as essential to the thing to be done; and they must then be regarded in the light of limitations upon the power to be exercised. It is the province of an instrument of this solemn and permanent character to establish those fundamental maxims, and fix those unvarying rules by which all departments of the government must at all times shape their conduct; and if it descends to prescribing mere rules of order in unessential matters, it is lowering the proper dignity of such an instrument, and usurping the proper province of ordinary legislation. We are not therefore to expect to find in a constitution provisions which the people, in adopting it, have not regarded as of high importance, and worthy to be embraced in an instrument which, for a time at least, is to control alike the government and the governed, and to form a standard by which is to be measured the power which can be exercised as well by the delegate as by the sovereign people themselves. If directions are given respecting the times or modes of proceeding in which a power should be exercised, there is at least a strong presumption that the people designed it should be exercised in that time and mode only; and we impute to the people a want of due appreciation of the purpose and proper province of such an instrument, when we infer that such directions are given to any other end. Especially when, as has been already said, it is but fair to presume that the people in their constitution have expressed themselves in careful and measured terms, corresponding with the immense importance of the powers delegated, and with a view to leave as little as possible to implication."

Judge Cooley apparently used the word "mandatory" as equivalent to a requirement of strict compliance. It is hardly possible to agree with his conclusion regarding the "high importance" attached by the people to some of the formal provisions in a state constitution. Examination of a modern state constitution (or of a state constitution at the time when Judge Cooley wrote) might perhaps have led the learned author to the view that there had been a "lowering of the proper dignity of such an instrument", if it be assumed that a state constitution should contain only matters of high importance. ${ }^{120}$ Many of the provisions establish nothing of principle, and oftentimes their violation can in no way injure either private rights or any well-considered public policy. The provision may be one purely of detail, frequently immaterial in itself, except for the fact that it is in the constitution, and its violation may be a mere harmless inadvertence. The form of an enacting clause required by a constitution is almost of necessity somewhat accidental, and the same statement applies to constitutional prescrip-

${ }^{200}$ As to state constitutions such an assumption runs contrary to the facts. See Dodd, The Function of a State Constitution (IgI5) 30 POL. SCI. Q. 201. 
tions as to the form of judicial process. It is of little material importance whether we have, "Be it enacted by the general assembly" or "Be it enacted by the people, represented in the general assembly".

An immaterial matter does not become important because it is found in a state constitution. And where a constitutional provision requires notice in a certain form for the protection of private rights, the courts will properly refuse to require compliance with such form, where the private rights have in fact been adequately protected. A similar point of view would support judicial disregard of a constitutional provision requiring publication of proposed constitutional amendments for twelve weeks in each county, if it could be shown that under state law copies of the proposed amendments, together with arguments opposing and supporting them, were actually placed in the hands of each voter. ${ }^{121}$

But in cases where constitutional provisions are capable of judicial enforcement, no large group of provisions has been held purely directory, although in a number of cases substantial compliance has been regarded as sufficient. The attitude of the courts in this matter is based in part upon their assumption that they are the only appropriate constitutional guardians, and that provisions are likely to be ignored if committed to the uncontrolled discretion of legislatures.

"To say that a provision is directory, seems, with many persons, to be equivalent to saying that it is not law at all. That this ought not to be so must be conceded; that it is so, we have abundant reason and good authority for saying. If, therefore, a constitutional provision is to be enforced at all, it must be treated as mandatory. And if the legislature habitually disregard it, it seems to us that there is all the more urgent necessity that the courts should enforce it." ${ }^{122}$

There is much truth to this statement though its principle does not apply (as courts seem to think) to legislatures alone. Constitutional provisions, mandatory in form, directed to the courts, appear just as likely to be disregarded because they are not made obligatory through compulsion external to the judicial department.

Yet, of course, the legislature is a body which must to a greater extent act affirmatively, and it therefore has a greater opportunity to ignore limitations upon it which may be regarded as purely directory. In so far as courts hold to be directory constitutional provisions which they may, if they desire, hold mandatory, they are, of course, taking a view favorable to legislatures, and raising implications favorable to legislative power; implications in this respect to some extent (though very slightly) modify the

Im Riesteterer v. Horton Land and Lumber Co., I60 Mo. I4I, 6I S. W. 238 (I90I); Wright v. Jordan, I92 Cal. 704, 221 Pac. 915 (I923).

${ }_{122}$ May v. Rice, $9 \mathrm{I}$ Ind. 546 (I883) quoted in Commonwealth v. Illinois C. R. R. Co., I6o Ky. 745, 750, 170 S. W. I7r, I73 (I9r4). 
general tendency to raise implications against state legislative power. ${ }^{123}$ In the development of constitutional texts, courts have been little encouraged to hold limitations upon legislatures to be directory rather than mandatory. The California Supreme Court originally held a constitutional provision regarding titles of acts to be directory, but changed its view because of the insertion into the California constitution of 1879 of a declaration that:

"The provisions of this constitution are mandatory and prohibitory, unless by express words they are declared to be otherwise."

Since 1879 six other states have followed California's example of inserting mandatory clauses into their constitutions. ${ }^{124}$ Such provisions have been referred to in several cases as having a decisive effect upon judicial construction of constitutional provisions. ${ }^{125}$ These declarations still leave it to the court to determine whether "mandatory" means literal or substantial compliance.

The largest single class of directory constitutional provisions is that relating to legislative procedure, and these provisions are not judicially enforcible primarily because no proof is permitted as to compliance or noncompliance with them. They may become mandatory at any time, if a court refusing to permit examination of journals changes its view as to this matter, but the tendency appears to be to give less rather than more weight to legislative journals, though such a tendency has had little influence as yet in the proposal of constitutional amendments.

\section{Provisions Mandatory in Form but Directory in Fact}

State constitutions have tended to contain an increasing number of provisions directing the legislature to take certain actions. For example, the constitution of Oklahoma provides that the legislature "shall establish and maintain a system of free public schools"; and "shall" make provision for decennial revisions of the statutes; and shall make a legislative reapportionment each ten years. There is no power in the court nor in any other department of the state government to compel affirmative legislative action, and provisions depending upon such action must to the extent of such dependence be directory. The South Dakota constitution required the legislature to provide a census in 1895 , and to make a legislative apportionment on the basis of such census. The court of that state said:

L. J. I37.

${ }^{2}$ Dodd, Implied Powers and Implied Limitations in Constitutional Law (I9I9) 29 YALE

${ }_{123}$ Montana (I889), North Dakota (I889), Washington (I889), Utah (I895), South Carolina (I895), Arizona (IgIo). See also the Alabama constitutional provision as to notice of special legislation, supra note 45 .

${ }^{15}$ State v. Tooker, I5 Mont. 8, 37 Pac. 840 (1894) ; Smith v. Jennings, 67 S. C. 324, 330, 45 S. E. 82 I, 823 (Ig03). 


\begin{abstract}
"The provisions of this section are in their nature mandatory to the legislature to enact the specified legislation. But under our system of government there is no power to compel the legislative department to enact laws. Constitutions may restrict legislative powers, and declare what laws shall not be valid; but from the very nature of legislative power, its exercise in a particular case must depend upon the volition of the legislature." 126
\end{abstract}

To say that such provisions are "in their nature mandatory" or obligatory is but another way of saying that they rest in the uncontrolled discretion of the legislature.

Efforts to obtain judicial enforcibility for such provisions have uniformly failed. The Washington court was unsuccessfully asked in I9I6 to hold an existing apportionment made in I90I invalid because the legislature had not performed the constitutional duty of making a new apportionment. ${ }^{127}$ In three successive cases the Illinois Supreme Court refused to consider: (I) mandamus to compel apportionment; (2) injunction to restrain payment of legislative salaries on the ground that the legislature had no lawful existence; and (3) quo warranto to test the lawful existence of the legislature. ${ }^{128}$

Under some conditions, however, it is possible to obtain judicial enforcibility of requirements as to affirmative legislative action. Where the requirement relates to form of legislative action, this is clearly possible, and the same thing is true to some extent where the requirement is bound up more or less intimately with action which the legislature must in fact take, even though it cannot be coerced into doing so. Provisions that the legislature shall appropriate money according to certain forms are not affirmatively enforcible in one sense, for the legislature cannot be coerced into making appropriations, ${ }^{129}$ but if appropriations must in fact be made, the constitutional forms of appropriation become then judicially enforcible. The same statement applies to formal requirements in connection with any necessary legislative action. The New Jersey constitution requires public notice of intention to apply for local or special legislation, and provides that:

"The legislature, at the next session after the adoption hereof [of this constitutional amendment], and from time to time thereafter, shall prescribe the time and mode of giving such notice, the evidence thereof, and how such evidence shall be preserved."

${ }^{20}$ In re State Census, 6 S. D. 540,62 N. W. 129 (I895). See also Gillinwater v. Mississippi and At1. R. R. Co., I3 I1l. I, 6 (I85I).

${ }^{27}$ State v. Howell, 92 Wash. 540, I59 Pac. 777 (Igr6).

${ }^{129}$ Fergus v. Marks, 321 I11. 510, I52 N. E. 557 (I926) ; Fergus v. Kinney, 333 I11. 437, 164 N. E. 665 (I928) ; People v. Blackwell, 342 Ill. 223, I73 N. E. 750 (I930).

${ }^{120}$ See State ex rel. Sutherland v. Nye, 23 N. 
The court could not compel the legislature to prescribe the required rules, but if the legislature had failed to do so, ${ }^{130}$ the court could have said that no local or special law would be treated as valid unless notice were proved in a manner prescribed by legislative action; the legislature would then have to act if it were to continue to exercise power to pass local or special laws.

Other illustrations suggest themselves, that are further removed from the field of legislative procedure. The Mississippi constitution required that "the legislature shall provide by law for determining contested elections". Now a legislature must almost necessarily pass laws providing for elections, and it would have been possible for a court to say that an election law is invalid unless it complies with the constitutional command regarding contested elections. Yet a court would be very unlikely to say this. Upon the issue here suggested the Mississippi court said:

"Suppose the legislature had failed to provide by law for contesting any elections, would any contend that the elections failed of their effect, and the popular will should be defeated, either by leaving offices vacant or by continuing the incumbents in office until the constitutional requirement should be obeyed? This would involve consequences not to be tolerated, and is suggestive of the unsoundness of any view which makes them possible. We reject any such view and hold that the provision of the constitution under consideration, like many others in it, is addressed to the legislature and mandatory upon it, but that it ends with that department. . . ."131

Suppose, again, that a constitutional provision should say that the legislature shall enact a law permitting the state to be sued upon claims against it, and that the legislature actually enacted such a law. The legislature now repeals the law without substituting anything in its place. It would be possible for a court to make the requirement to some extent mandatory (assuming the legislature had once acted affirmatively), by saying that a repeal was invalid which resulted in a complete negation of the constitutional command. But it is extremely unlikely that a court would take such a view. ${ }^{132}$

Some element of actual compulsion presents itself with respect to legislative apportionments, if an alternative plan may be employed, should the legislature fail to reapportion at the proper time, even though the alternative plan is itself not subject to judicial enforcement. Such a plan was unsuccessfully employed in Missouri for a time, and has been adopted in California. Congress, in 1929, provided for executive action in con-

${ }^{200}$ The legislature did make the required provision. Passaic County v. Stevenson, 46 N. J. L. I73, I86 (I884).

${ }^{151}$ Dictum in Schulherr v. Bordeaux, 64 Miss. 59, 70, 8 So. 201 (1886). (1875).

232 See the view as to language held directory in form, in Ex parte State, 52 Ala. 23I 
gressional reapportionment, should the two houses fail to act, and the present congressional apportionment is the result of executive rather than legislative action. The constitutions of Ohio and Maryland prescribe the rules of legislative apportionment, and commit power to act to executive officers. ${ }^{133}$

Although there are elements of judicial enforcibility in certain constitutional provisions requiring affirmative legislative action, these elements are usually not present, and where they are, courts are loath to take advantage of them. In general, therefore, constitutional provisions that the legislature "shall" do a certain thing are equivalent to statements that the legislature "may" or "shall have power". ${ }^{134}$ The Federal Constitution provides that Congress "on the application of the legislatures of two-thirds of the several states, shall call a convention for proposing amendments" to the constitution, but there is no compulsion upon Congress to call a convention.

If the people in framing a constitution or a constitutional amendment desire to make sure that a provision will be effective without reliance upon action within the uncontrolled discretion of the legislature, they must put the matter into the constitution in such detail and in such form that it becomes self-executing. ${ }^{135}$ The constitution itself may, through self-executing provisions, look directly to the people whose actions are to be controlled, and not to the people indirectly through a requirement of legislative action. A popular vote in New York in 1886 was overwhelmingly in favor of calling a constitutional convention, but owing to political differences between the legislature and the governor the convention was not assembled until I894. The New York constitution of 1894 provides for the assembling of a convention without legislative action.

A constitutional amendment for the initiative and referendum, adopted by Utah in I900, adopted these institutions under certain conditions "as may be provided by law". Nothing could be done until the legislature acted,

${ }^{123}$ Dopd, op. cit. supra note I8, at ${ }_{15}$ I. In Massachusetts apportionment of representatives within counties is committed to county commissioners in each county, and the courts will enforce affirmative action. Merrill v. County Commissioners of Essex, 257 Mass. I84, 153 N. E. 562 (1926). The same statement applies to the apportionment of assemblymen by the board of aldermen of the City of New York. Matter of Livingston, 96 Misc. 34I, I60 N. Y. Supp. 462 (Y916).

134 For a view that in a constitution "may" should not be construed as mandatory, see State ex rel. Greaves v. Fenry, 87 Miss. I25, 40 So. I.52 (1905).

${ }_{335}$ "There appear to be three classes of provisions in the constitution. The first class embraces constitutional provisions negative and prohibitory in their character, and are selfexecuting. . . . The second class embraces such constitutional provisions as require certain provisions to be had in order to render valid the enactment of laws or the accomplishment of the purposes of the legislature. These provisions must be substantially complied with, or the laws enacted or the proceedings taken may be invalid. The third class embraces provisions requiring the legislature to enact certain laws, but prescribes no penalty for a failure to perform the duty". In re State Census, 6 S. D. 540, 62 N. W. I29 (I895).

Judge Cooley well states the test of self-executing provisions: "A constitutional provision may be said to be self-executing if it supplies a sufficient rule by means of which the right given may be enjoyed and protected, or the duty imposed may be enforced. . . " $O P$. cit. supra note 3 , at 167. See ibid. 165-171. 
and the legislature took no action until I917. All of the initiative and referendum amendments adopted by other states since this time except that of Idaho in IgIz provide the details for the operation of the system, while at the same time expressly permitting legislation to supplement these provisions; some expressly say that the constitutional provisions shall be selfexecuting. Constitutional changes with respect to the process of amending the constitution of North Dakota omitted certain details (which were apparently not fatal to the self-executing character of the provision), and did not provide expressly that the constitutional terms should be self-executing; the North Dakota court, unnecessarily, held that the provisions required legislative action to make them operative, but later changed its position, saying that there were no presumptions in favor of the necessity of legislative action. ${ }^{136}$ The North Dakota court quoted the Supreme Court of California with approval, to the effect that:

"Now the presumption is the reverse. Recently adopted state constitutions contain extensive codes of laws, intended to operate directly upon the people as statutes do. To say that these are not selfexecuting may be to refuse to execute the sovereign will of the people. The different policy requires a different ruling. I should say the rule now is, that such constitutional provisions must be held to be selfexecuting when they can be given reasonable effect without the aid of legislation, unless it clearly appears that such was not intended." ${ }^{137}$

Self-executing provisions are, of course, also limitations (and mandatory limitations) upon the legislature, in that they occupy a field previously occupied by the legislature, and in that the legislature may not run counter to them. Implications against legislative power are easily drawn from such provisions. When the constitution directly legislates it reduces legislative power often to as great an extent as when it directly prohibits or restricts legislative action.

Constitutional provisions to the effect that the legislature "shall" take certain action or that it "may" or "shall have power" to do certain things in some cases affirmatively enlarge legislative powers beyond those previously recognized by the courts. Several constitutional amendments were adopted by the State of Ohio in I912 for the express purpose of permitting legislative action in cases where the courts had held such action improper. ${ }^{138}$

While provisions requiring affirmative legislative action have at times been adopted primarily for the purpose of enlarging legislative power or of emphasizing the existence of such power, and may not be enforced through

${ }^{120}$ State v. Hall, 35 N. D. 34, x35 N. W. 28I (1916); State v. Hall, 44 N. D. 459, I7I N. W. 213 (I9I9). On self-executing provisions see also Parwal Investment Co. v. State, 7I Okla. I2I, I75 Pac. 514 (I918), and Scopes v. State, I54 Tenn. 105, 289 S. W. 363 (I927).

${ }^{237}$ Winchester v. Howard, 136 Cal. 432, 439, 69 Pac. 77, 78 (1902).

${ }^{129}$ Dodd, op. cit. supra note I8, at I25. 
coercion upon the legislature, they are by implication held in many cases to impose restrictions upon legislative action and are to that extent mandatory. So, if a constitution says that the legislature "shall" make an apportionment each ten years, courts may not compel the legislature to make such an apportionment, but they may say that the affirmative command contains a negative and mandatory prohibition against making an apportionment oftener than once in the ten year period. ${ }^{139}$ Such mandatory limitations are, however, drawn with equal ease from provisions that are affirmatively directory ("may") as from those that are affirmatively mandatory ("shall"). A clear illustration presents itself in the case of Scott $v$. Flowers. 140 The Nebraska constitution provided that the legislature may establish reform schools for children under the age of sixteen. This was clearly directory not only in effect, but also in form, yet the court drew from it a mandatory limitation against providing reform school facilities for children of more than sixteen. The theory that a state constitution is a limitation and not a grant of power no longer holds when many provisions are inserted into a constitution for the purpose of making sure that a power will not be judicially denied. In recognition of this fact, the framers of the Oklahoma constitution of 1907 inserted a statement that "any specific grant of authority in this Constitution, upon any subject whatever, shall not work a restriction, limitation or exclusion of such authority upon the same or any other subject or subjects whatsoever." 141

\section{Political Questions and Other Issues of Which the Courts DeCline JuRISDiction}

The term "political question" is employed to designate certain types of functions committed to the political organs of government (the legislative and executive departments, or either of them), and not subject to judicial investigation. ${ }^{142}$ Where a function is in terms committed exclusively and finally to another department of government, judicial control over such function is expressly or impliedly negatived. The same principle applies where the Constitution of the United States commits a function exclusively to a state body or a state officer. In Kentucky $v$. Dennison the United States Supreme Court said that the performance of the duty of one state upon proper demand to deliver up a fugitive from justice to another state "is left to depend on the fidelity of the state executive to the compact entered into with the other states when it adopted the Constitution of the

1so People v. Carlock, I98 Ill. I50, 65 N. E. Iog (Ig02); Dowell v. McLees, I99 Cal. I44, 248 Pac. 5 II (I926).

${ }_{140} 60$ Neb. 675,84 N. W. 8 I (I900).

1si Oklahoma constitution, art. $5, \S 36$. Prairie Oil and Gas Co. v. District Court, 7I Okla. 32, I74 Pac. I056 (I918).

${ }_{102}$ For issues similar to "political questions" in the sense in which that term is used above, see a statement of English Law, Moore, Acr of State in ENGLish LAw (1906). 
United States and became a member of the Union." 143 Political questions, properly so called, are ones committed to other than judicial organs of government, not in terms excluding judicial control, but with respect to issues so distinctly political in character that courts regard it as improper to seek to exercise control, although in the exercise of the jurisdiction conferred upon it by the Constitution, the United States Supreme Court may feel called upon to determine issues equally as delicate as those which it avoids. ${ }^{144}$

So far as concerns the national government, the subject of political questions has been frequently and adequately discussed. ${ }^{145}$ The conduct of foreign relations is, of course, entirely removed from judicial control.146 Of a similar type is the question as to the propriety of calling out the militia in any case. The political relationships between state and nation are also matters with respect to which an attempt to exercise judicial authority might well be futile. So the United States Supreme Court declined to exercise jurisdiction upon application for an injunction presenting the question of the political status of the state of Georgia, saying that "the rights, for the protection of which our authority is invoked, are the rights of sovereignty, of political jurisdiction, of government, of corporate existence as a state, with all its constitutional powers and privileges." 147

Under the Constitution "the United States shall guarantee to every state in this Union a republican form of government, and shall protect each of them against invasion; and on the application of the legislature, or of the executive (when the legislature cannot be convened) against domestic violence." The courts have no control over military forces, and the duty to protect from invasion or domestic violence is necessarily imposed upon other organs of government. Where domestic violence is due to two contending bodies, each claiming to be the legitimate state government, the national organs, whose function it is to protect from domestic violence, must necessarily determine which of such bodies is the legitimate one. ${ }^{148}$ And the guaranty of a republican form of government is one to be enforced, not by the judicial, but by the political organs of the national government. ${ }^{149}$

${ }^{113}$ Kentucky v. Dennison, 24 How. 66, I09 (U. S. 1860).

rs The court has decided state boundary disputes presenting serious problems and has determined when a state is within the Union. Texas v. White, 7 Wall. 700 (U. S. I869). The case of Arizona v. California, 283 U. S. 423, 5 I Sup. Ct. 522 (I93I) involved issues as serious as some that have been avoided.

${ }^{145}$ For one of the most recent discussions, see 3 Willoughay, Constitutuonal Law (2d ed. I929) I326-1338. The problem is adequately discussed by Field, The Doctrine of Political Questions in the Fedcral Courts (I924) 8 MinN. L. Rev. 485 . See also Finkelstein, Judicial Self-Limitation (1924) 37 HARv. L. Rev. 338; Weston, Political Questions (1925) 38 Harv. L. Rev. 296; Finkelstein, Frurther Notes on Judicial Self-Limitation (1925) 39 HARV. L. REv. 22I.

${ }^{1+5}$ See recent discussions in Russian Republic v. Cibrario, 235 N. Y. 255, 139 N. E. 259 (1923); United States v. Snyder, 44 Fed. (2d) 895 (Ct. of App. D. C. 1930).

1*7 Georgia v. Stanton, 6 Wall. 50 (U. S. I868).

${ }^{138}$ Luther v. Borden, 7 How. I (U. S. I849).

${ }_{119}$ Pacific States Tel. and Tel. Co. v. Oregon, 223 U. S. II8, 32 Sup. Ct. 224 (I9I2); State $e x$ rel. Davis v. Hildebrant, $24 I$ U. S. 565,36 Sup. Ct. 708 (I9I6); Akron Park District v. Ohio, 28I U. S. 74, 5blesippnlGt. 2280(193a)L. Rev. 85 1931-1932 
Most of the questions just referred to are ones that present themselves in the national government, but not in the states. Questions of foreign relations and of relations between state and nation in the United States are ones to be settled by national, not by state, authority. Political questions are therefore relatively much less important in state constitutional law.

But questions do present themselves in the states somewhat similar to those in the national government. For example, state courts have said that it is improper for them to contradict assertions made by the political organs of government regarding state boundaries. ${ }^{150}$ And several state courts have taken a strong position against judicial interference with acts undertaken through state military power, in connection with the suppression of disorder. ${ }^{151}$ The question whether a state capital is being properly removed from one location to another appears, however, to be open to state judicial inquiry. ${ }^{152}$

If observance of the federal provision guaranteeing a republican form of government is not subject to inquiry in federal courts, it would seem more clearly beyond the authority of state courts. Yet early cases holding local option laws unconstitutional were based to some extent on the theory that such laws violated a guaranty of republican form of government, and some modern state cases on the initiative, referendum and recall have discussed and decided issues as to what constitutes a republican form, under the federal guaranty. These state decisions have been liberal in their definition of a republican form of government but the courts have decided the question, ${ }^{153}$ and a political question is properly one which the courts decline to discuss, because of its character. We have a somewhat curious situation of an issue of federal guaranty being political from the standpoint of federal courts, and judicial from the standpoint of some state courts. In a proposed constitution submitted to and rejected by the people of Illinois in I922, a provision was inserted that "the republican form of government of this state shall never be abandoned, modified or impaired". Had this provision been adopted, the question of its observance would apparently have been subject to judicial control. The purpose may have been merely to repeat the federal guaranty, but state enforcement of such a guaranty

${ }^{150}$ Bedel v. Loomis, II N. H. 9 (1840); State v. Wagner, 6I Me. I78 (I873).

151 Fatrman, The Law of Martial Rule (I930) I52-157, and articles by Professor $H$. W. Ballantine, Martial Law (I9I2) I2 Con L. Rev. 529; Qualified Martial Law, A Legislative Proposal (I915) I4 Mich. L. Rev. I02, I97. See also Note (I913) 45 L. R. A. (N. S.) 996 to the West Virginia case of Mays v. Brown (I9I2). But see also Ex parte Lavinder, 88 W. Va. 713, I08 S. E. 428 (192I).

${ }^{152}$ State ex rel. Attorney General v. Huston, 27 Okla. 606, II3 Pac. I90 (I9Io). See also Slack v. Jacob, $8 \mathrm{~W}$. Va. 6r2 (1875).

${ }^{153}$ Kiernan v. Portland, 57 Ore. 454, III Pac. 379 (I9I0) ; Bonner v. Belsterling, I04 Tex. 432, I38 S. W. 57 I (I9II) ; Hile v. Cleveland, I07 Ohio St. I44, I4I N. E. 35 (I923); State ex rel. Topping v. Houston, 94 Nieb. 445,452 , I43 N. W. 796,799 (I9I3). See also Note (I908) 4 M ICH. L. REv. 304. 
would have presented none of the political problems involved in enforcing a federal guaranty with respect to the states.

A situation akin to that presented by political questions arises with respect to judicial control over the heads of state and national executive departments. The principle is well established that, where a discretion is conferred upon an administrative officer, whether superior or inferior, the courts will not interfere to control the manner of exercising that discretion (unless in case of fraud or abuse of power). The discretion is one of another department, and only action resulting from its abuse is judicially cognizable. This principle applies to a subordinate administrative officer as well as to the governor or the president. But with respect to the head of an executive department a further principle has been adopted by many courts; mandamus will not issue to compel even the performance of a purely ministerial function by the governor, ${ }^{154}$ and in some states the fact that the governor is a member of a board will cause the courts to decline to issue mandamus to the board. ${ }^{155}$ In the states adopting the principle that action of the governor, even though ministerial, cannot be judicially coerced, a function committed to the governor personally by the constitution, or in which the governor's action is necessary under the constitution, is incapable of judicial control. Substantially the same statement may be made regarding the injunction, for the more general view is that the courts may not enjoin actions by the governor; ${ }^{156}$ here, however, the freedom from judicial control is not so great, for if the governor's action must be through his subordinates, an injunction may issue against them, though cases in West Virginia and Pennsylvania suggest that immunity extends to officers acting under the governor's directions.

Until recently the constitution of Missouri provided under certain conditions for a senatorial apportionment board composed of the governor, secretary of state and attorney general. The governor declined to act with the other two, who together then prepared an apportionment; but the constitution provided that such apportionment should come into effect "upon the proclamation of the governor". The governor declined to proclaim the apportionment and the court refused to coerce him, ${ }^{157}$ although it said

${ }^{26}$ Notes (Ig07) 6 L. R. A. (N. s.) 750 ; (IgII) 32 L. R. A. (N. s.) 355 ; and (IgI7) L. R. A. I9I7F, 774. Myers, Mandamus against a Governor (1905) 3 MICH. L. Rev. 63I. But see Winsor v. Hunt, 29 Ariz. 504, 243 Pac. 407 (1926) ; State v. Henderson, I99 Ala. 244, 74 So. 344 (I9I7); Gordon v. Morrow, I86 Ky. 713, 218 S. W. 258 (1920).

${ }^{15}$ People $e x$ rel. Bruce v. Dunne, 258 Ill. 44I, IOI N. E. 560 (xgI3). But see Brunson v. Commissioners of Land Office, 145 Okla. 219, 292 Pac. 562 (1930).

15) Slack v. Jacob, 8 W. Va. 6I2 (I875) ; State ex rel. Attorney General v. Huston, 27 Okla. 606, II3 Pac. I90 (I9Io); State v. District Court, I56 Minn. 270, 194 N. W. 630 (1923); Putnam v. Norblad, 293 Pac. 940 (Ore. I93I). As to the issue of judicial process to the governor in general, see Thompson v. German Valley Railroad Co., 22 N. J. Eq. III (187I), and Hartranft's Appeal, $85 \mathrm{~Pa} .433$ (I877).

${ }_{15 \pi}$ State ex rel. Barrett v. Hitchcock, 24I Mo. 433, 146 S. W. 40 (19I2). For a failure of a legislative appropriation through refusal of the governor to authorize payment, see State ex rel. Robb v. Stone, I20 MqI478 of 
that the two could lawfully act in making the apportionment after the governor's refusal to join with them. In Oklahoma an injunction was sought to prevent a removal of the state capital by the governor and other state officers; proceeding by injunction against the governor was declined, but as to other officers jurisdiction was taken and the matter determined on its merits. ${ }^{158}$ It is usually possible, if the governor acts through subordinates, to contest his action judicially by mandamus, injunction, or civil action against the subordinates. Where the power, and under the constitution, a duty to act, is committed to the governor alone, no remedy may be had against his inaction (in the states declining to mandamus him) and a duty imposed upon him in mandatory constitutional language is directory in effect, just as is mandatory language addressed to the legislature.

Elections are regarded as so far political in their nature that courts will not ordinarily interfere with them by injunction, and some courts apply this rule strictly with respect to the submission of questions to popular vote by legislative action. Such a vote is by some courts regarded as involving purely political rights-by others as a step in the legislative process. ${ }^{150}$ Jurisdiction over election contests is normally statutory, and by statute the Supreme Court of South Dakota is given jurisdiction over election contests for state offices. ${ }^{160}$ By statute in Wisconsin power is committed to the courts to determine whether expenses of an election are excessive, and in the exercise of this power the courts may declare an election for governor void. ${ }^{161}$ But, in the absence of statute, judicial inquiry will often be made as to rights depending upon an election, where the determination has not been exclusively committed to other departments by the constitution. ${ }^{162}$ State courts have passed upon the issue presented by two contesting legislative bodies, ${ }^{163}$ and upon contests regarding an election to the governorship. ${ }^{164}$ The Nebraska court assumed jurisdiction to pass upon the qualifications of a candidate for governor who had been declared elected by the

${ }^{109}$ State ex rel. Attorney General v. Huston, 27 Okla. 606, II3 Pac. I9o (I9Io). In West Virginia judicial power was denied even as against officers acting under direction of the governor. Slack v. Jacob, $8 \mathrm{~W}$. Va. 612 (I875).

${ }^{150} \mathrm{McAlister}$ v. State, 95 Okla. 200, 219 Pac. 134 (1923) and Note (1924) 33 A. L. R. I376; McAlister v. State, 96 Okla. I43, 22I Pac. 779 (I923) ; Spies v. Byers, 287 Ill. 627, 122 N. E. 84I (I919); State ex rel. Stokes et al. v. Roach, 269 Mo. 500, 190 S. W. 277 (I916); Weinland v. Fulton, 99 Ohio St. I0, I2I N. E. 816 (IgI8); Gaskins v. Dorsey, 150 Ga. 638, I04 S. E. 433 (I920).

${ }^{100}$ Harries v. McCrea, 62 Utah 348, 219 Pac. 533 (1923); Ewing v. Harries, 68 Utah 452, 250 Pac. 1049 (I926); Warren v. Brown, 234 N. W. 38 (S. D. 1930).

${ }^{101}$ State v. Kohler, 200 Wis. 518,228 N. W. 895 (I930).

102 Cooley, op. cit. supra note 3 , at 1408 et seq. State v. Circuit Court, I78 Wis. 468 , 190 N. W. 563 (1922).

${ }^{163}$ Prince v. Skillen, 7x Me. 36I (I880) ; In re Gunn, 50 Kan. 155, 32 Pac. 470 (1893).

${ }^{16 s}$ Attorney General v. Barstow, 4 Wis. 567 ( 1856 ) ; State v. Bulkeley, 6I Conn. 287, 23 At1. I86 (1892). 
two houses of the legislature. ${ }^{165}$ And the Texas court recently passed upon the qualifications of a candidate for governor of that state, although saying that the matter was not one for judicial determination. ${ }^{166}$

In many fields the tendency of state courts has been to narrow the scope of what might otherwise have been regarded as political questions. Most of the state constitutions prescribe, often in a good deal of detail, methods of legislative apportionment; the view that an apportionment when made is not subject to judicial control has been rejected by state courts with the possible exception of Virginia, the question of difference in the decisions being that as to the strictness or liberality of judicial attitude toward legislative apportionments. ${ }^{167}$ The constitutions of New York and Oklahoma expressly provide for judicial review of apportionments. Delay in the contest of apportionments may, however, introduce a political element of which the courts will take cognizance. ${ }^{168}$

In Luther v. Borden, ${ }^{169}$ Chief Justice Taney said:

"In forming the constitutions of the different states after the Declaration of Independence, and in the various changes and alterations which have since been made, the political department has always determined whether the proposed constitution or amendment was ratified or not by the people of the state, and the judicial power has followed its decision."

The view recently expressed by the United States Supreme Court in Leser v. Garnett ${ }^{170}$ is in accord with Chief Justice Taney's statement, and at one time it seemed possible that this view might prevail in state courts, ${ }^{171}$ but state constitutional provisions regarding constitutional amendment have become judicially cognizable, except as to steps in such process committed exclusively to other departments. ${ }^{172}$ The determination of what ought to go into an amendment (including of course the regulation by amendment of matters previously regulated by statute) is necessarily committed to the

${ }^{10}$ State v. Boyd, 3I Neb. $682,48 \mathrm{~N}$. W. 739 (I89I), rev'd on the question of citizenship, Boyd v. Nebraska, I43 U. S. I35, I2 Sup. Ct. 375 (I892).

${ }^{100}$ Dickson v. Strickland, II4 Tex. 176, 265 S. W. IOI2 (I924).

Ior See People v. Carlock, Ig8 I1l. I50, 65 N. E. I09 (I902), and cases cited in State ex rel. Barrett v. Hitchcock, $24 \mathrm{I}$ Mo. 433,473, I 46 S. W. 40,53 (I9I2). ReINSCH, AMERICaN Legrslatures aNd LEgislatrve MEthods (I9I3)' Ig6-212. That a congressional determination of the time when an apportionment comes into effect is political, see State v. Boyd, $36 \mathrm{Neb} .18 \mathrm{I}, 54 \mathrm{~N}$. W. 252 (I893). Upon judicial control of apportionments, see Wise v. Bigger, 79 Va. 269 (1884).

${ }^{10}$ See infra notes I83-185.

1077 How. I, 39 (U. S. I849).

${ }^{170} 258$ U. S. I30, 42 Sup. Ct. 217 (I922).

${ }^{171}$ Dodd, op. cit. supra note 4, at 209-215.

${ }^{272}$ For a review of cases upon amending process and a comment upon the commission to other departments of functions connected therewith, see McConaughy v. Secretary of State, I06 Minn. 392, 410, I19 N. W. 408, 415 (1909). See also Boyd v. Olcott, IO2 Ore. 327, 202 Pac. 43I (Ig2I). 
discretion of the bodies proposing amendments, though an opposing view is taken in an indefensible decision of the Missouri Supreme Court. ${ }^{173}$

In the field of judicial non-enforcibility, interesting problems present themselves with respect to cases involving normally justiciable issues but in which the courts either decline to take jurisdiction or decline to pass upon certain of the issues submitted to them. The United States Supreme Court properly avoided the decision of political questions in Mississippi $v$. Johnson ${ }^{174}$ and Georgia v. Stanton, ${ }^{175}$ but when proper parties appeared, the avoidance of a decision regarding the constitutionality of the reconstruction acts was accomplished in the end only by a statutory change in the appellate jurisdiction of the court. ${ }^{176}$ It may be, as Professor Corwin has ably argued, that there are no constitutional limits upon the power of Congress to spend money, ${ }^{177}$ but the judicial settlement of this constitutional issue seems improbable so long as the United States Supreme Court adheres to the view that neither a state nor an individual has a sufficient interest to raise the question for judicial decision. ${ }^{37 s}$

But in an even larger group of cases, courts decline to pass upon constitutional questions although the issues are justiciable and have been raised by proper parties. This is accomplished by applying to certain constitutional questions a judicial principle similar in some respects to a statute of limitations.

There are some cases in which constitutional changes, once consummated, become so political in their aspects that a court will decline to interfere. In both Kentucky and Virginia effort was made to contest complete constitutions already in operation, and courts declined to inquire into irregularities in the action leading to the adoption of such constitutions. ${ }^{179}$ Once a government is in operation, a court, constituting part of the organization thereunder, could hardly declare that government ineffective. Consummation of. a change may in such a case make the question political, although it may properly have been subject to judicial cognizance had the issue been presented earlier. Somewhat the same situation presents itself

${ }^{173}$ State ex rel. Halliburton v. Roach, 230 Mo. 408, I30 S. IV. 689 (I9Io), abandoned in part in State ex rel. Stokes et al. v. Roach, supra note I59. See also Livermore v. Waite, I02 Cal. II3, 36 Pac. 424 (I894). The United States Supreme Court has wisely rejected contentions that would require judicial inquiry into the proper content of a constitutional amendment. United States v. Sprague, 5I Sup. Ct. 220 (U. S. I93I).

${ }^{173} 4$ Wall. 475 (U. S. 1867 ).

1756 Wall. 50 (U. S. I868).

${ }^{278}$ Ex parte McCardle, 7 Wall. 506 (U. S. I869).

${ }^{17}$ Corwin, The Spending Power of Congress (I923) 36 HARv. L. REv. 548. And see Arizona v. California, 283 U. S. 423, 5I Sup. Ct. 522 (I93I) in which the Supreme Court appears to have regained for the federal government much more power than it surrendered in Kansas v. Colorado, 206 U. S. 46, 26 Sup. Ct. 655 ( 1907 ).

${ }_{178}$ Massachusetts v. Mellon, 262 U. S. 447, 43 Sup. Ct. 597 (I923). See also Fairchild v. Fughes, 258 U. S. 126, 42 Sup. Ct. 274 (1922); New Jersey v. Sargent, 269 U. S. 328, 46 Sup. Ct. 122 (1925).

${ }_{170}$ DoDD, op. cit. supra note 4, at 96-102, 222-225. The matter is discussed in Ellingham v. Dye, I78 Ind. 336,99 N. E. I (1912). 
as to a constitutional amendment materially changing governmental organization, if the amendment had been put into operation and continued in effect for a number of years. ${ }^{180}$ The question is not at first political in its nature, but becomes so because lapse of time has made it so. The Pennsylvania court has recently taken the view that no judicial attack may be made upon a constitutional amendment after its approval by the people, and the California court appears to have reached the same result. ${ }^{181}$

Many courts have also taken the view that delay may destroy the right to contest the validity of legislative acts creating new counties or making other types of territorial reorganization. ${ }^{182}$ With respect to apportionment acts, the courts have shown a natural reluctance to hold an act invalid and thus force a return to an earlier and less satisfactory system than the one that is destroyed. The Indiana Supreme Court refused to hold an apportionment invalid when to do so would leave no basis for the election of a legislature unless an extra session should be called and a new apportionment act passed; ${ }^{183}$ and in a proceeding by mandamus to contest an apportionment, the Wyoming court said that "in order to entitle the relators to the writ it is incumbent upon them to show a prior apportionment to fall back to". ${ }^{184}$ The Washington court in I9I6 quoted with approval language used by the Kentucky court in an earlier case:

"It may be true the laches cannot give validity to a void act, but when no property right is involved, and the question is purely political and administrative, individuals or parties that have seen the act in operation for years, and the affairs of state carried on under it, without offering objection or making protest, will not be heard at a late day to question its validity." 185

With respect to other types of legislation, the Supreme Court of Illinois has adopted the principle that "when a statute has long been treated by the courts as constitutional and important rights have become established thereunder, the courts may thereafter refuse to consider its constitutionality." 186 This rule has been definitely applied when parties have sought to take ad-

${ }^{\text {Iso }}$ Nesbit v. People, 19 Colo. 441, 36 Pac. 221 (I894) ; Weston v. Ryan, 70 Neb. 211, 97 N. W. 347 (Ig03).

${ }^{152}$ See supra notes 107 and 108.

${ }^{152}$ Nagel v. Bosworth, I48 Ky. 807, I47 S. W. 940 (I9I2) ; Hurley v. Motz, I5I Ky. 45I, 152 S. W. 248 (I913); State ex rel. West v. Des Moines, 96 Iowa 521,65 N. W. 818 (I896); People v. Alturas County, 6 Idaho 4I8, 5.5 Pac. I067 (I899); Note (I908) I3 L. R. A. (N. s.) 534.

${ }^{2 \times 3}$ Fessler v. Brayton, I4.5 Ind. 71, 44 N. E. 37 (1895).

${ }^{184}$ State v. Schnitzer, 16 Wyo. 479, 95 Pac. 698 (I908).

${ }^{15 s}$ State ex rel. Warson v. Howell, 92 Wash. 540, 546, I59 Pac. 777, 779 (I916), quoting Adams v. Bosworth, I26 Ky, 61, I02 S. W. 86I (rg07). Upon this matter see also People v. Rice, I35 N. Y. 473, 31 N. E. 92I (18y2) ; State v. Stoddard, 25 Nev. 452, 62 Pac. 237 (I900).

${ }^{180}$ Meister v. Carbaugh, 3 Io I11. 486, 488, I42 N. E. I89, I90 (I924) ; People v. Bergin, 340 I1l. 20, 25, I72 N. E. 60, 62 (r 
vantage of procedural defects in the enactment of statutes. And the State of New Jersey since 1873 has authorized the governor or any two or more citizens to institute proceedings within one year to determine whether a law or resolution was not duly passed or duly approved "as required by the constitution of the state". The statute authorizing this proceeding, when construed in the light of judicial unwillingness to examine journal entries in New Jersey, substantially forbids contest of general statutes beyond the period of one year with respect to procedural defects disclosed only by the legislative journals. ${ }^{187}$

\section{CONCLUSION}

The field of judicial non-enforcibility is important, but is not large when contrasted with the whole body of written constitutional texts. The exceptions from judicial enforcibility fall primarily within the field of public or governmental interests. Moreover, aside from a limited number of cases in which the judicial attitude is dictated by a wise political expediency, the primary issues in this field present themselves with respect to formal and procedural requirements of state constitutions. Judicial control over legislation is a political institution, and must be tested by the results of its operation. Would better or worse results come from an extension of judicial control to cover the present field of judicial non-enforcibility? ${ }^{188}$

When courts have assumed authority to decide issues involving political interests, they have not always inspired public confidence. It will always be remembered that the judicial members of the Electoral Commission of I876 voted in accord with their political affiliations. A judicial effort to enforce the duty of state executives with respect to interstate rendition would almost of necessity have worked less well than a plan of placing that responsibility upon the executives themselves. Government is after all a political institution, and political problems are better solved outside the court room. If courts attempt their solution they fail and cripple themselves in the performance of functions properly judicial. At the same time they reduce the feeling of responsibility that should exist in the department charged with the power or duty to act.

With respect to formal and procedural matters, the judicial record does not lend much support to an argument for an extended jurisdiction. The reports contain too many hair-splitting decisions as to journal entries, sufficiency of title, and other matters of this character. By the doctrine of "substantial compliance" the courts have in many cases reached commonsense results. Constitutional requirements as to procedure in the enactment

in See supra notes 69-72 and N. J. Comp. STAт. (I9I0) 4978-4980.

188 The suggestion that judicial power be extended to the field of political questions appears to assume that such an extension is desirable. Albertsworth, Constitutional Duties and Inadequate Enforcement Machinery (I93I) I7 A. B. A. J. I53. 
of legislation and in the proposal and adoption of constitutional amendments are primarily for the purpose of preventing surprise or concealment, and Professor Freund, some years ago, wisely suggested that there should be a limitation upon the time within which contest of constitutionality may be made because of failure to comply with such formal and procedural requirements. ${ }^{189}$ Some courts have in part reached this result by declining to permit contest after undue delay, and New Jersey has accomplished much the same purpose by statute. With respect to constitutional amendments recent Pennsylvania decisions forbid contest on procedural grounds after popular approval. ${ }^{190}$ The growing tendency to regard the enrolled bill as final has an element of distinct value, though the rule may be pushed too far when the courts defeat an effort to show that through fraud a measure has come to have the form of law although never enacted by the legislature.

A constitutional provision not judicially enforcible in one state may be so enforcible in another. For example, constitutional requirements as to titles of bills are generally held to be mandatory, but are held to be directory in Ohio. ${ }^{191}$ Perhaps it would be difficult to discover more abuse in Ohio than in the other states. Certainly, anyone who has found it necessary to read a mass of judicial decisions as to titles of bills and as to what constitutes one subject in the enactment of legislation is likely to be convinced that the net loss is greater than the net gain in the judicial application of these requirements. Declarations of emergency under the referendum are subject to judicial control in Washington, but not in Oregon, and it may be difficult to discover material differences in the results; just as differences in the formal procedure of legislative bodies may be difficult to discover in those recognizing or refusing to recognize the finality of an enrolled bill. Moreover, a constitutional provision may be judicially enforcible in the same state at one time and not at another. The strongest advocates of complete judicial enforcibility would probably not regret that the concluding terms of an indictment in Missouri first ceased to be literally binding and later became merely directory.

"We are much too apt to think of the judicial power of disregarding the acts of the other departments as our only protection against oppression and ruin." The forces that compel compliance with political safeguards and with the essential requirements in the passage of laws and the adoption of constitutional changes are not judicial-they are stronger than this, and their strength is largely dependent upon the degree of final responsibility placed upon the political organs of government.

${ }^{150}$ Freund, The Problem of Adequate Legislative Powers under State Constitutions (IgI4) 5 Proc. Acad. Pol. ScI. 98, I07-108.

${ }_{10}$ See supra notes 107, IOS. If a state does not permit attack after popular adoption, it must permit proceedings to prevent submission of the question to popular vote and cannot follow the decisions cited in supra note 159. Armstrong v. King, 28I Pa. 207, 126 At1. 263 (I924).

III The constitutional langträininMis 